\title{
Multi-environment Evaluation of Maize Inbred Lines for Resistance to Fusarium Ear Rot and Fumonisins
}

L. J. Rose, M. Mouton, and I. Beukes, Department of Plant Pathology, Stellenbosch University, Matieland 7602, South Africa; B. C. Flett, Grain Crops Institute, Agricultural Research Council, Potchefstroom 2520, South Africa; C. van der Vyver, Institute for Plant Biotechnology, Stellenbosch University; and A. Viljoen, Department of Plant Pathology, Stellenbosch University

\begin{abstract}
L. J. Rose, M. Mouton, I. Beukes, B. C. Flett, C. van der Vyver and A. Viljoen, 2016. Multi-environment evaluation of maize inbred lines for resistance to Fusarium ear rot and fumonisins. Plant Dis. 100:2134-2144.

Fusarium verticillioides causes Fusarium ear rot (FER) of maize and produces fumonisins, which affects grain quality. Host-plant resistance can reduce both FER and fumonisins in maize. In this study, 18 maize inbred lines were evaluated for resistance to $F$. verticillioides and fumonisin accumulation at five localities in South Africa. Additive main effects and multiplicative interaction analyses revealed significant environment $\times$ genotype interactions, with inbred lines CML 390, US 2540W, RO 424W, and VO 617y-2 consistently exhibiting low FER

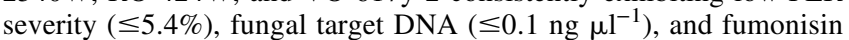

levels $(\leq 5.6 \mathrm{ppm})$. Genotype main effect and genotype $\times$ environment biplots showed that inbred lines CML 390, US 2540W, and RO 424W were most resistant to FER, fungal colonization, and fumonisin accumulation, respectively, while inbred line RO $424 \mathrm{~W}$ was most stable in its resistance response over environments. These inbred lines also demonstrated broad adaptability by consistently exhibiting resistance to FER, fungal colonization, and fumonisins across localities. The identified lines could serve as valuable sources of resistance against $F$. verticillioides and its fumonisins in local breeding programs.
\end{abstract}

The fungus Fusarium verticillioides (Sacc.) Nirenberg is commonly associated with maize (Zea mays L.) (Kommedahl and Windels 1981). It is the fungus most commonly associated with maize produced in South Africa and causes Fusarium ear rot (FER), along with $F$. subglutinans (Wollenw. \& Reinking) P. E. Nelson, Toussoun \& Marasas and F. proliferatum, (Matsush.) Nirenberg, which occur less frequently (Boutigny et al. 2012; Ncube et al. 2011). The fungus can also cause root and stalk rot (Kommedahl and Windels 1981; Munkvold et al. 1997). F verticillioides can also colonize vegetative and reproductive tissues without showing any disease symptoms (Bacon and Hinton 1996; Foley 1962; Munkvold et al. 1997). Silks and wounds caused by insects are considered the most common infection pathways (Headrick and Pataky 1991; Munkvold and Carlton 1997; Munkvold et al. 1997; Smeltzer 1959), while systemic infection through seed and roots has also been demonstrated (Munkvold et al. 1997; Oren et al. 2003; Wu et al. 2011). The subsequent development of FER reduces both the yield and quality of maize, and can result in economic losses.

A significant concern associated with $F$. verticillioides infection is the production of mycotoxins, called fumonisins, in maize grain (Gelderblom et al. 1988). Fumonisins consist of a family of at least 28 analogs, of which fumonisins $\mathrm{B}_{1}, \mathrm{~B}_{2}$, and $\mathrm{B}_{3}$ are the most common (Shephard et al. 1996). Fumonisin $B_{1}$ has been associated with human diseases such as esophageal cancer (Franceschi et al. 1990; Marasas et al. 1981; Rheeder et al. 1992), neural tube defects in newborn babies (Missmer et al. 2006), and predisposition to Human immunodeficiency virus (Williams et al. 2010). In animals, it has been responsible for leukoencephalomalacia in horses (Marasas et al. 1988; Kellerman et al. 1990), liver cancer in rats (Gelderblom et al. 1994), and neurodegeneration in mice (Osuchowski et al. 2005). Due to the prevalence of fumonisins in maize and maize-based products intended for human and animal consumption, many countries have introduced maximum tolerable levels for the toxin (Bolger et al. 2001; CFSAN 2001). South Africa,

Corresponding authors: L. J. Rose;

E-mail: lindym@sun.ac.za; and A.Viljoen; E-mail: altus@sun.ac.za

Accepted for publication 30 April 2016.

http://dx.doi.org/10.1094/PDIS-11-15-1360-RE

(C) 2016 The American Phytopathological Society however, has no legislation on the maximum tolerable limit of fumonisin in maize and maize-based products, despite fumonisin levels in rural areas exceeding tolerable limits enforced in Europe and the United States (Ncube et al. 2011; Shephard 2008; Shephard et al. 2007).

Improving host resistance in locally adapted maize cultivars is an affordable and environmentally sound method to reduce high fumonisin levels in food and feed. This strategy, however, has yet to be commonly employed in breeding programs to address the mycotoxin problem (Clements and White 2004). This is due to the polygenic, quantitative nature of resistance to FER and fumonisin accumulation that makes breeding for resistance particularly challenging. Quantitative trait loci (QTL) for resistance to FER and fumonisins have been shown to have relatively small effects and are inconsistent between populations (Pérez-Brito et al. 2001; Robertson-Hoyt et al. 2006). More often, sources that exhibit high levels of ear rot resistance are from older or exotic germplasm and lack desirable agronomic traits (Clements and White 2004; Eller et al. 2008, 2010). Thus, breeders are confronted with the difficulty of introducing polygenic resistance alleles of small effect linked to inferior polygenic alleles for agronomic performance into elite breeding gene pools from unadapted lines (Zila et al. 2013).

The genetic potential for resistance to FER is strongly influenced by the environment. Therefore, inbred lines found to be resistant at one location may respond differently when tested at a different location due to their genotype $\times$ environment interaction (GEI) (Robertson-Hoyt et al. 2006; Shelby et al. 1994; Small et al. 2012). The effect of GEI on plant response complicates selection of superior genotypes due to their different ranking from one location to another. The changes in a genotype's ranking make it more difficult to draw reliable conclusions regarding genotype performance in different environments (Mitrovic et al. 2012). Numerous reports have highlighted the effect of GEI on FER severity and fumonisin accumulation in maize (Afolabi et al. 2007; Clements et al. 2004; Small et al. 2012). In a study by Shelby et al. (1994), maize genotypes grown outside of their normal production areas were likely to be more susceptible to FER and fumonisin contamination. Environmental factors are extremely important for fumonisin contamination because high levels of fumonisins are associated with hot, dry weather followed by periods of high humidity (Shelby et al. 1994).

The stability of genotype response is an important consideration to ensure the commercial success of a cultivar. Stability may be defined by the consistency of genotype performance across environments and is affected by the GEI (Riaz et al. 2013). However, Robertson 
et al. (2006) determined that differences in genotypes, rather than a lack of correlation among genotype performances at different environments, primarily contributed to the significant GEI effects. Identifying stable sources of resistance in locally adapted breeding material should, therefore, accelerate the development of resistant cultivars. Although resistant inbred lines have been identified for central and western African countries (Afolabi et al. 2007), their adaptation to South African environmental conditions would be time consuming. Their resistance under local conditions also first will have to be validated.

A small number of resistant inbred lines have recently been identified in South Africa (Small et al. 2012). In this study, these lines and additional breeding material of desirable agronomic performance were evaluated in multilocation trials over 2 years to determine whether their resistance to FER and fumonisin accumulation was stable across diverse environments.

\section{Materials and Methods}

Plant material evaluated. Eighteen maize inbred lines (Table 1) selected by plant breeders at the Agricultural Research CouncilGrain Crops Institute (ARC-GCI) in Potchefstroom, South Africa were evaluated for resistance to FER, fungal colonization, and fumonisin accumulation. These included seven elite maize inbred lines with excellent yield potential but whose status in relation to FER and fumonisin contamination was unknown. Inbred lines previously characterized as resistant, intermediately resistant, and susceptible to FER and fumonisin accumulation in two localities (Small et al. 2012) were also included in the study. All inbred lines had superior agronomical traits and represented a diverse genetic background.

Field trials. Maize inbred lines were planted at five localities, each differing in macro- and microclimatic conditions, during the 2010-11 season and at four localities during the 2011-12 growing season. The field locations included Buffelsvallei (grid reference: $26^{\circ} 48^{\prime} \mathrm{S}, 26^{\circ} 61^{\prime} \mathrm{E}$; altitude, $1,383 \mathrm{~m}$; 2010-11 season only) and Potchefstroom (grid reference: $26^{\circ} 73^{\prime} \mathrm{S}, 27^{\circ} 07^{\prime} \mathrm{E}$; altitude, $1,349 \mathrm{~m}$ ) in the Northwest province, Vaalharts (grid reference: $27^{\circ} 95^{\prime} \mathrm{S}, 24^{\circ} 83^{\prime} \mathrm{E}$; altitude, $1,180 \mathrm{~m}$ ) in the Northern Cape province, and Cedara (grid reference: $29^{\circ} 54^{\prime} \mathrm{S}$, $30^{\circ} 26^{\prime} \mathrm{E}$; altitude, $1,068 \mathrm{~m}$ ) and Makhatini (grid reference: $22^{\circ} 39^{\prime} \mathrm{S}$, $32^{\circ} 17^{\prime} \mathrm{E}$; altitude, $77 \mathrm{~m}$ ) in the KwaZulu-Natal province (Table 1). Standard procedures to prepare fields were followed at all the trial locations. Maize kernels were hand planted (two seeds per hill) in 10-m plots, with an intrarow spacing of $0.3 \mathrm{~m}$ and an interrow spacing of $1 \mathrm{~m}$. The trials were planted using a randomized complete block design and replicated three times, with experimental plots thinned to 33 plants per plot 3 weeks after emergence. The Potchefstroom, Buffelsvallei, and Makhatini trials were conducted under dryland conditions while the Potchefstroom and Makhatini trials were supplemented with overhead irrigation when required. The Cedara trials were irrigated with a central pivot system, whereas the Vaalharts trials were flood irrigated on a weekly basis. Weather data, including the maximum temperature, rainfall, and humidity for December to June of each year, were obtained from the ARC's weather stations located at each respective locality (Table 2).

Table 1. Maize inbred lines evaluated for resistance to Fusarium ear rot (FER), Fusarium verticillioides colonization, and fumonisin accumulation in South Africa during the 2010-11 and 2011-12 maize-growing seasons

\begin{tabular}{|c|c|c|c|c|c|c|}
\hline \multirow[b]{2}{*}{ Entry number } & \multirow[b]{2}{*}{ Inbred line name } & \multirow[b]{2}{*}{ Line code } & \multirow[b]{2}{*}{ Institution $^{y}$} & \multicolumn{3}{|c|}{ Main traits ${ }^{x}$} \\
\hline & & & & Response & Color & Protein \\
\hline 1 & VO $617 y-2$ & 3 & ARC-GCI, South Africa & Resistant $^{\mathrm{z}}$ & Yellow & High lysine \\
\hline 2 & K64R-22 & 4 & ARC-GCI, South Africa & Intermediate $^{\mathrm{Z}}$ & White & Normal \\
\hline 3 & I 16 & 5 & ARC-GCI, South Africa & Unknown & White & Unknown \\
\hline 4 & I 34 & 6 & ARC-GCI, South Africa & Unknown & White & Unknown \\
\hline 5 & R2565y & 7 & ARC-GCI, South Africa & Susceptible ${ }^{\mathrm{z}}$ & Yellow & Normal \\
\hline 6 & RO 549W & 8 & ARC-GCI, South Africa & Resistant $^{\mathrm{Z}}$ & White & High lysine \\
\hline 7 & US 2540 & 9 & ARC-GCI, South Africa & Resistant $^{\mathrm{z}}$ & White & Normal \\
\hline 8 & I 35 & 10 & ARC-GCI, South Africa & Unknown & White & Unknown \\
\hline 9 & $\mathrm{RO} 424 \mathrm{~W}$ & 12 & ARC-GCI, South Africa & Intermediate $^{\mathrm{z}}$ & White & High lysine \\
\hline 10 & RO 544W & 13 & ARC-GCI, South Africa & Susceptible $\mathrm{z}$ & White & High lysine \\
\hline 11 & I 9 & 14 & ARC-GCI, South Africa & Unknown & White & Unknown \\
\hline 12 & I 37 & 16 & ARC-GCI, South Africa & Unknown & White & Unknown \\
\hline 13 & I-B & 17 & ARC-GCI, South Africa & Intermediate ${ }^{\mathrm{z}}$ & White & Normal \\
\hline 14 & CML 444 & 18 & CIMMYT, Zimbabwe & Resistant $^{\mathrm{Z}}$ & White & Normal \\
\hline 15 & R119W & 19 & ARC-GCI, South Africa & Resistant $^{\mathrm{z}}$ & White & Normal \\
\hline 16 & CB 222 & 20 & ARC-GCI, South Africa & Unknown & White & Unknown \\
\hline 17 & CB 248 & 21 & ARC-GCI, South Africa & Unknown & White & Unknown \\
\hline 18 & CML 390 & 22 & CIMMYT, Zimbabwe & Resistant $^{\mathrm{z}}$ & White & Normal \\
\hline
\end{tabular}

${ }^{x}$ Main traits include inbred line response to $F$. verticillioides and fumonisin accumulation, kernel color, and protein content.

y ARC-GCI = Agricultural Research Council-Grain Crops Institute and CIMMYT = International Maize and Wheat Improvement Center.

${ }^{\mathrm{z}}$ According to Small et al. (2012).

Table 2. Maximum temperature, relative humidity, and maximum rainfall at multiple field locations in South Africa during the 2010-11 and 2011-12 maizegrowing seasons ${ }^{\mathrm{y}}$

\begin{tabular}{|c|c|c|c|c|c|c|c|c|c|c|}
\hline \multirow[b]{2}{*}{ Location } & \multirow[b]{2}{*}{ Locality $\operatorname{code}^{\mathrm{z}}$} & \multicolumn{3}{|c|}{ Maximum temperature $\left({ }^{\circ} \mathrm{C}\right)$} & \multicolumn{3}{|c|}{ Relative humidity (\%) } & \multicolumn{3}{|c|}{ Maximum rainfall (mm) } \\
\hline & & 2010-11 & 2011-12 & Combined & 2010-11 & 2011-12 & Combined & $2010-11$ & 2011-12 & Combined \\
\hline Buffelsvallei & B10 & $25.7 \mathrm{~d}$ & & $25.7 \mathrm{c}$ & $93.5 \mathrm{ab}$ & & $93.5 \mathrm{a}$ & $130.5 \mathrm{a}$ & & $130.5 \mathrm{a}$ \\
\hline Cedara & $\mathrm{C} 10, \mathrm{C} 11$ & $24.1 \mathrm{f}$ & $24.6 \mathrm{ef}$ & $24.4 \mathrm{~d}$ & $95.9 \mathrm{a}$ & $95.7 \mathrm{a}$ & $95.8 \mathrm{a}$ & $87.8 \mathrm{bc}$ & $55.8 \mathrm{c}-\mathrm{e}$ & $71.8 \mathrm{bc}$ \\
\hline Potchefstroom & $\mathrm{P} 10, \mathrm{P} 11$ & $30.9 \mathrm{a}$ & $31.0 \mathrm{a}$ & 30.9 a & $89.8 \mathrm{~cd}$ & $91.6 \mathrm{bc}$ & $90.7 \mathrm{~b}$ & $55.5 \mathrm{c}-\mathrm{e}$ & $36.7 \mathrm{de}$ & $46.1 \mathrm{~cd}$ \\
\hline Makhatini & M10, M11 & $25.2 \mathrm{de}$ & $26.7 \mathrm{c}$ & $25.9 \mathrm{c}$ & $89.9 \mathrm{~cd}$ & $86.7 \mathrm{~d}$ & $88.3 \mathrm{bc}$ & $115.0 \mathrm{ab}$ & $68.7 \mathrm{~cd}$ & $91.8 \mathrm{~b}$ \\
\hline Vaalharts & V10, V11 & $28.4 \mathrm{~b}$ & $30.3 \mathrm{a}$ & $29.4 \mathrm{~b}$ & $90.6 \mathrm{bc}$ & $82.9 \mathrm{e}$ & $86.7 \mathrm{c}$ & $21.1 \mathrm{e}$ & $41.0 \mathrm{de}$ & $31.0 \mathrm{~d}$ \\
\hline
\end{tabular}

y Combined $=$ means calculated across seasons and localities. Means followed by the same letter in each column as well as across the 2010-11 and 2011-12 seasons are not significantly different according to the Student's $t$ test of least significant differences $(P \geq 0.05)$.

${ }^{\mathrm{z}}$ Buffelsvallei 2010-11 = B10, Cedara 2010-11 and 2011-12 = C10 and C11, Makhatini 2010-11 and 2011-12 = M10 and M11, Potchefstroom 2010-11 and 2011-12 = P10 and P11, and Vaalharts 2010-11 and 2011-12 = V10 and V11. 
Fungal isolates and production of inoculum. Well-characterized isolates of $F$. verticillioides, obtained from infected maize grain collected at the same production areas as the trial locations, were used in this study. Isolates GCI 315 and GCI 790 were collected from infected maize in Ndwedwe (KwaZulu-Natal) and Rushof (Northern Cape), respectively, whereas MRC 826, a prolific producer of fumonisin $B_{1}$, was isolated from infected maize in the Transkei region (Eastern Cape). Conidial suspensions were prepared according to Small et al. (2012) to a concentration of $1 \times 10^{6}$ spores $\mathrm{ml}^{-1}$, and equal volumes of each conidial suspension combined to produce the final inoculum. The inoculum was kept at $4^{\circ} \mathrm{C}$ prior to and during the inoculation process, and inoculum viability was confirmed by fungal growth on potato dextrose agar plates following the field inoculation.

Artificial inoculation and visual assessment of disease severity. The primary ear of each plant was inoculated approximately 14 days after silking by injecting a conidial cocktail $(2 \mathrm{ml})$ down the silk channel with a sterile Terumo needle $(18 \mathrm{G} \times 38 \mathrm{~mm})$ and syringe (Afolabi et al. 2007). Inoculated maize ears were manually harvested once the grain was dry (12 to $18 \%$ moisture), dehusked, and subjected to visual assessment of FER symptoms. Disease severity was determined by estimating the percentage of each inoculated ear (0 to $100 \%)$ covered by visible symptoms of infection, which included kernel rot, white to pink fungal mycelium, pink or brown discoloration of intact kernels, as well as the "starburst" symptom characterized by white streaking radiating from the cap of the kernels (Duncan and Howard 2010; Koehler 1942). Following disease assessment, maize ears were dried to $12 \%$ moisture, mechanically shelled, and bulked per trial plot. A 250-g kernel sample was taken from each bulked plot and ground to produce maize flour using a Cyclotech sample mill (Foss Tecator, Hoganas, Sweden). The mill was thoroughly cleaned with high-pressure air between each sample to avoid cross contamination. Flour samples were stored at $-20^{\circ} \mathrm{C}$ until the extraction of fumonisins and genomic DNA was performed.

Quantification of $\boldsymbol{F}$. verticillioides in maize grain. The $F$. verticillioides isolate MRC 826 was used to produce DNA standards for the absolute quantification of this ear rot pathogen in maize samples. DNA was extracted from fungal cultures and 2-g milled maize samples (Boutigny et al. 2012), and the quantity and purity of the DNA was determined with a NanoDrop ND-1000 Spectrophotometer (Inqaba Biotechnical Industries [Pty] Ltd., Pretoria, South Africa). The DNA was then diluted to a concentration of $10 \mathrm{ng} \mu \mathrm{l}^{-1}$ and stored at $-20^{\circ} \mathrm{C}$ until the amount of fungal target DNA (translation elongation factor $1 \alpha$ gene) in maize samples was determined by quantitative real-time polymerase chain reaction (qPCR) according to Boutigny et al. (2012).

A standard curve was first prepared by diluting $F$. verticillioides MRC 826 DNA (16.1 ng $\mu l^{-1} ; 4^{1}$ to $4^{6}$-fold) in maize DNA that was free of fungal contamination $\left(10 \mathrm{ng}^{-1} \mathrm{l}^{-1}\right)$ to determine the quantification of fungal DNA. The standard curve was subjected to a strict set of criteria consisting of a slope of between -3.1 and -3.6 and linearity above 0.98 . In addition, the $\Delta \mathrm{Ct}$ between extrapolated and measured cycle threshold $(\mathrm{Ct})$ number of the undiluted sample was $<0.5$ (CRL-EM-01/08, 2008). Regression equations of standard curves created to detect $F$. verticillioides in the maize samples were highly significant $\left(R^{2}>0.99\right)$. After generating the standard curve, the fungal and maize dilutions $\left(2^{2}-, 2^{3}\right.$-, and $2^{4}$-fold $)$ were stored at $-20^{\circ} \mathrm{C}$ as positive controls for future inclusion in qPCR assays. Following each assay, the standard curve was imported to determine the concentration of fungal target DNA in environmental samples. The sensitivity of the qPCR assay to detect and quantify isolates GCI 315 and GCI 790 was confirmed prior to the analysis of maize samples. DNA from maize samples were analyzed in duplicate while standard pathogen DNA (16-fold dilution of pathogen DNA in clean maize DNA) and DNA-free water were included as positive and negative controls, respectively.

Fumonisin quantification. Fumonisins were extracted from 5-g milled maize samples as follows. Methanol extraction buffer $(20 \mathrm{ml}$; $\mathrm{MeOH} /$ high-performance liquid chromatography [HPLC]-grade water, 70:30) was added to each sample and the suspension shaken at $200 \mathrm{rpm}$ in an incubator-shaker set at $25^{\circ} \mathrm{C}$ for $30 \mathrm{~min}$. The samples were then centrifuged at $1,576 \mathrm{rpm}$ at $4^{\circ} \mathrm{C}$ for $10 \mathrm{~min}$. A sterile syringe was used to remove $\pm 2 \mathrm{ml}$ of supernatant which was filtered through a $0.20-\mu \mathrm{m}$ recombinant cellulose filter into a 2-ml Eppendorf tube. The samples were kept at $4{ }^{\circ} \mathrm{C}$ overnight, after which they were centrifuged for $10 \mathrm{~min}$ at $14,000 \mathrm{rpm}$ before they were transferred to liquid chromatography tandem mass spectrometry (LC-MS/MS) glass vials. Samples for fumonisin analysis were diluted in a 1:1 ration with HPLC-grade water and sent to the Central Analytical Facility at Stellenbosch University for the quantification of $\mathrm{FB}_{1}, \mathrm{FB}_{2}$, and $\mathrm{FB}_{3}$.

LC-MS/MS analysis. Fumonisin contamination of maize samples was determined by a dilute-and-shoot method using LC-MS/MS. It was performed on a Quattro Micro triple quadrupole mass spectrometer from Waters/Micromass (Manchester, UK), equipped with an Alliance 2695 HPLC system (Waters) and Mass Lynx NT software 4.1 for data acquisition and processing. The electrospray ionization source was used in the positive mode and the settings were optimized for the best sensitivity. The mass spectrometer was operated in the multiple reaction monitoring mode with argon employed as collision gas, and a cone voltage of $25 \mathrm{~V}$ was used for all transitions. The following transitions were used: for fumonisin $\mathrm{B}_{1}, 722.4>352.2$ and 722.4 > 334.4; and, for fumonisin $\mathrm{B}_{2}$ and $\mathrm{B}_{3}, 706.0>318.4$ and $706.0>336.4$, respectively, at a collision energy of $40 \mathrm{eV}$.

Fumonisin standards $\left(B_{1}[10 \mathrm{mg}], B_{2}[10 \mathrm{mg}]\right.$, and $B_{3}[1 \mathrm{mg}]$ ), guaranteed $95 \%$ pure, were obtained from the Medical Research Council's Program on Mycotoxins and Experimental Carcinogenesis, Tygerberg, South Africa. Reconstituted standards were utilized in a dilution series that ranged between 0.05 and $20 \mathrm{mg} \mathrm{kg}^{-1}$ for $\mathrm{FB}_{1}$ and $\mathrm{FB}_{2}$, and between 0.005 and $2 \mathrm{mg} \mathrm{kg}^{-1}$ for $\mathrm{FB}_{3}$. A calibration curve was performed with each set of samples analyzed, and a nontoxin control represented by pure $\mathrm{MeOH} / \mathrm{HPLC}$-grade water (70:30) was included. Each standard and sample $(5 \mu \mathrm{l})$ was injected into the LC-MS/MS system, and samples with results above the calibration curve limits were diluted and reanalyzed. After the volume of extract used in the purification procedure was adjusted, the minimum limits of quantification for $\mathrm{FB}_{1}, \mathrm{FB}_{2}$, and $\mathrm{FB}_{3}$ were $0.02,0.002$, and $0.02 \mathrm{ppm}$, respectively.

Data analysis. The data obtained from the visual assessment of FER symptoms, $F$. verticillioides target DNA, and fumonisin quantification were subjected to combined analysis of variance (ANOVA) to determine GEI. Using Proc GLM of SAS statistical software (version 9.2; SAS Institute Inc., Cary, NC), the ANOVA demonstrated the presence of GEI. Nonparametric Pearson correlation coefficients were used to determine the relationships among FER symptoms, fungal target DNA quantified, and total fumonisins accumulated using the CORR procedure in SAS based on log-transformed means.

GEI were investigated by fitting an additive main effects and multiplicative interaction (AMMI) to the data using Genstat v16 (Payne et al. 2013). The AMMI model partitioned GEI into the first and second interaction principal components axes (IPCA) and residual. The stability of the genotypes across locations was determined by the AMMI stability values (ASV) (Purchase et al. 2000), which is based on the first and second IPCA scores of the AMMI model for each genotype. The distance from a genotype's coordinate point to the origin in a two-dimensional scatter diagram determines the ASV value. Therefore, genotypes with the lowest ASV values exhibit the shortest projection from the biplot origin and are considered the most stable.

The genotypic means relative to the principal components (PC) was graphically represented in genotype main effect and genotypeenvironment (GGE) biplots generated in GenStat v16. The first PC (PC1), located on the $\mathrm{X}$-axis, indicates the level of resistance, where inbred lines with higher PC1 values (positive or negative) are considered low risk to FER, $F$. verticillioides colonization, and fumonisin accumulation. The second PC (PC2), located on the Y-axis, represents performance stability of genotypes, where $\mathrm{PC} 2$ values near zero demonstrate greater adaptability of genotypes to different environments (Yan and Kang 2003). The GGE biplot graphically represented the genotype main effect and GEI (Yan 2001; Yan et al. 2000). The method is based on evaluating genotypes, first by considering only the effects of the genotype and GEI as significant, while simultaneously taking these variables $(\mathrm{G}+\mathrm{GE})$ into consideration. Second, it enabled the evaluation and representation of genotypes in different environments using the biplot technique (Gabriel 1971). 
The "ideal genotype for a particular environment" or the "which won where" model was used to designate a mega-environment. Megaenvironments represent the localities in which the best-performing genotype is common to the same environments consistently across years. The estimation of resistance and stability of genotypes to FER, $F$. verticillioides colonization, and fumonisin accumulation was evaluated by an average environment coordination (AEC) method (Yan 2001; Yan et al. 2000). It uses the average PC in all environments, represented as a circle, with a line drawn through the average environment and the biplot origin called the average environment axis (AEA).

The perpendicular line passing through the AEA and the biplot origin, called the average ordinate environment (AEO), divides genotypes exhibiting above-average (to the right of the AEO) and below-average (to the left of the AEO) resistance. Genotypes are projected on the AEA and ranked on resistance (low FER, $F$. verticillioides target DNA, and fumonisins), with increased resistance in the direction of the arrow. The arrow points to a greater genotype main effect while the AEC ordinate and either direction away from the biplot origin indicate greater GEI effect and reduced stability. Concentric circles visualize the distance between each genotype and the ideal genotype, with a genotype being more desirable if it is located close to the ideal genotype. GGE biplots were constructed with genotype-focus and symmetrical scaling.

\section{Results}

FER severity. Disease severity on maize ears was significantly $(P<0.05)$ influenced by environment, genotype, and interactions between these factors (Table 3); therefore, the mean FER severity is given for each locality and year of evaluation (Table 4). The interaction between genotype and environment explained $42.8 \%$ of the total variation $(\mathrm{G}+\mathrm{E}+\mathrm{GEI})$ observed, while genotype and environment explained 34.3 and $21.9 \%$ of the variation observed, respectively. The first and second IPCA were both significant $(P=0.00)$, while PCA1 of the interaction accounted for $28.2 \%$ of the total GEI variation for FER severity and PCA2 explained an additional $23.7 \%$ of the observed variation (Table 3). Thus, the two PCA accounted for $51.9 \%$ of the variability in FER disease expression.

The ASV, indicative of the stability of the genotypes' response across locations, ranged between 0.20 and 1.67 (Table 5). Inbred lines I 34 (0.20), CB 248 (0.23), and RO 549W (0.37) were most stable in their response to FER development across locations, while

Table 3. Additive main effects and multiplicative interaction (AMMI) analysis of variance (ANOVA) of Fusarium ear rot (FER), Fusarium verticillioides colonization, and total fumonisin content of maize inbred lines evaluated in South Africay

\begin{tabular}{|c|c|c|c|c|c|c|c|}
\hline \multirow[b]{2}{*}{ Source of variation $\mathrm{z}$} & \multirow[b]{2}{*}{ df } & \multicolumn{2}{|c|}{ FER severity } & \multicolumn{2}{|c|}{ F. verticillioides colonization } & \multicolumn{2}{|c|}{ Total fumonisins } \\
\hline & & MS & Total variation $(\%)$ & MS & Total variation $(\%)$ & MS & Total variation $(\%)$ \\
\hline Treatment & 161 & $3.03 *$ & 100.0 & $2.90 *$ & 100.0 & $2.30 *$ & 100.0 \\
\hline Environment & 8 & $13.31 *$ & 21.9 & $12.52 *$ & 21.4 & $20.25 *$ & 43.7 \\
\hline Block & 18 & $4.61 *$ & $\ldots$ & 0.69 & $\ldots$ & 0.24 & $\ldots$ \\
\hline Genotype & 17 & $10.12 *$ & 35.3 & $7.84^{*}$ & 28.5 & $3.13 *$ & 14.3 \\
\hline Interaction & 136 & $1.53 *$ & 42.8 & $1.72 *$ & 50.1 & $1.15^{*}$ & 42.0 \\
\hline IPCA1 & 24 & $2.45^{*}$ & 28.2 & $3.50 *$ & 35.9 & $2.77 *$ & 42.7 \\
\hline IPCA2 & 22 & $2.24 *$ & 23.7 & $2.31 *$ & 21.7 & $1.50 *$ & 21.2 \\
\hline Residual & 90 & $1.12 *$ & $\ldots$ & $1.10 *$ & $\ldots$ & $0.63 *$ & $\ldots$ \\
\hline Error & 306 & 0.53 & $\ldots$ & 0.48 & $\cdots$ & 0.23 & $\ldots$ \\
\hline Total & 485 & 1.51 & $\ldots$ & 1.29 & $\ldots$ & 0.92 & $\ldots$ \\
\hline
\end{tabular}

${ }^{y}$ Natural $\log$ transformation used in analyses; $\mathrm{df}=$ degrees of freedom, MS = mean square, and $*$ indicates significant at $P<0.05$.

$\mathrm{z}$ Treatment $=$ sum of environment, genotype, and interaction as sources of variation; and IPCA = interaction principal component axis scores.

Table 4. Fusarium ear rot symptoms of 18 maize inbred lines planted at multiple field locations in South Africa during the 2010-11 and 2011-12 maize-growing seasons

\begin{tabular}{|c|c|c|c|c|c|c|c|c|c|c|c|c|}
\hline \multirow[b]{3}{*}{ Inbred name } & \multirow[b]{3}{*}{ Line code } & \multicolumn{11}{|c|}{ Fusarium ear rot severity $(\%)^{y}$} \\
\hline & & \multicolumn{2}{|c|}{ Buffelsvallei } & \multicolumn{2}{|c|}{ Cedara } & \multicolumn{2}{|c|}{ Makhatini } & \multicolumn{2}{|c|}{ Potchefstroom } & \multicolumn{2}{|c|}{ Vaalharts } & \multirow[b]{2}{*}{ Combined $^{\mathrm{z}}$} \\
\hline & & 2010-11 & 2011-12 & 2010-11 & 2011-12 & 2010-11 & 2011-12 & 2010-11 & 2011-12 & 2010-11 & 2011-12 & \\
\hline VO $617 y-2$ & 3 & $1.5 \mathrm{~d}$ & $\ldots$ & $0.9 \mathrm{~h}$ & $3.6 \mathrm{a}-\mathrm{c}$ & $3.0 \mathrm{bc}$ & $9.8 \mathrm{bc}$ & $2.8 \mathrm{de}$ & $0.0 \mathrm{~d}$ & $1.4 \mathrm{fg}$ & $12.6 \mathrm{c}-\mathrm{e}$ & $4.0 \mathrm{fg}$ \\
\hline K64R-22 & 4 & $23.5 \mathrm{bc}$ & $\ldots$ & $33.5 \mathrm{a}-\mathrm{c}$ & $10.1 \mathrm{a}$ & $0.5 \mathrm{bc}$ & $7.8 \mathrm{bc}$ & $30.7 \mathrm{ab}$ & $10.3 \mathrm{~b}-\mathrm{d}$ & $12.9 \mathrm{ab}$ & $5.0 \mathrm{ed}$ & $14.9 \mathrm{~b}-\mathrm{d}$ \\
\hline $\mathrm{I}-16$ & 5 & $21.0 \mathrm{bc}$ & $\ldots$ & $37.0 \mathrm{ab}$ & $6.9 \mathrm{ab}$ & $4.0 \mathrm{bc}$ & $14.7 \mathrm{bc}$ & $23.8 \mathrm{a}-\mathrm{c}$ & $1.2 \mathrm{~d}$ & $6.9 \mathrm{~b}-\mathrm{g}$ & $18.7 \mathrm{a}-\mathrm{d}$ & $14.9 \mathrm{~b}-\mathrm{d}$ \\
\hline I-34 & 6 & $21.8 \mathrm{bc}$ & $\ldots$ & $8.9 \mathrm{e}-\mathrm{h}$ & $5.1 \mathrm{a}-\mathrm{c}$ & $3.8 \mathrm{bc}$ & $9.7 \mathrm{bc}$ & $22.6 \mathrm{a}-\mathrm{c}$ & $18.1 \mathrm{~b}-\mathrm{d}$ & $10.4 \mathrm{a}-\mathrm{c}$ & $23.4 \mathrm{a}-\mathrm{c}$ & $13.7 \mathrm{~cd}$ \\
\hline $\mathrm{R} 2565 \mathrm{y}$ & 7 & $13.8 \mathrm{~cd}$ & $\ldots$ & $5.2 \mathrm{f}-\mathrm{h}$ & $1.0 \mathrm{bc}$ & $12.5 \mathrm{a}$ & $6.5 \mathrm{bc}$ & $23.3 \mathrm{a}-\mathrm{c}$ & $3.0 \mathrm{~cd}$ & $0.3 \mathrm{~g}$ & $31.8 \mathrm{ab}$ & $10.8 \mathrm{de}$ \\
\hline RO 549W & 8 & $1.3 \mathrm{~d}$ & $\ldots$ & $15.9 \mathrm{~d}-\mathrm{h}$ & $0.9 \mathrm{bc}$ & $0.5 \mathrm{bc}$ & $12 \mathrm{bc}$ & $15.7 \mathrm{~b}-\mathrm{e}$ & $0.0 \mathrm{~d}$ & $7.5 \mathrm{~b}-\mathrm{f}$ & $2.5 \mathrm{e}$ & $6.3 \mathrm{e}-\mathrm{g}$ \\
\hline US 2540W & 9 & $0.5 \mathrm{~d}$ & $\ldots$ & $3.1 \mathrm{gh}$ & $0.0 \mathrm{c}$ & $2.5 \mathrm{bc}$ & $3.4 \mathrm{c}$ & $0.9 \mathrm{e}$ & $1.6 \mathrm{~d}$ & $2.2 \mathrm{e}-\mathrm{g}$ & $1.3 \mathrm{e}$ & $1.7 \mathrm{~g}$ \\
\hline I-35 & 10 & $40.5 \mathrm{a}$ & $\ldots$ & $27.4 \mathrm{a}-\mathrm{d}$ & $3.0 \mathrm{bc}$ & $1.8 \mathrm{bc}$ & $10.3 \mathrm{bc}$ & $28.8 \mathrm{a}-\mathrm{c}$ & $40.8 \mathrm{a}$ & $8.9 \mathrm{~b}-\mathrm{e}$ & $12.6 \mathrm{c}-\mathrm{e}$ & $19.4 \mathrm{ab}$ \\
\hline RO $424 W$ & 12 & $2.9 \mathrm{~d}$ & $\ldots$ & $2.0 \mathrm{~h}$ & $2.3 \mathrm{bc}$ & $4.8 \mathrm{bc}$ & $14 \mathrm{bc}$ & $5.5 \mathrm{de}$ & $3.3 \mathrm{~cd}$ & $4.6 \mathrm{c}-\mathrm{g}$ & $21.8 \mathrm{a}-\mathrm{d}$ & $6.8 \mathrm{ef}$ \\
\hline RO $544 W$ & 13 & $3.6 \mathrm{~d}$ & $\ldots$ & $22.2 \mathrm{~b}-\mathrm{e}$ & $6.9 \mathrm{ab}$ & $2.1 \mathrm{bc}$ & $2.2 \mathrm{c}$ & $3.9 \mathrm{de}$ & $0.0 \mathrm{~d}$ & $2.7 \mathrm{~d}-\mathrm{g}$ & 4.8 ed & $5.4 \mathrm{fg}$ \\
\hline I-9 & 14 & $29.3 \mathrm{ab}$ & $\ldots$ & $31.3 \mathrm{a}-\mathrm{d}$ & $5.9 \mathrm{a}-\mathrm{c}$ & $5.1 \mathrm{~b}$ & $16.3 \mathrm{a}-\mathrm{c}$ & $28.3 \mathrm{a}-\mathrm{c}$ & $11.4 \mathrm{~b}-\mathrm{d}$ & $9.7 \mathrm{a}-\mathrm{d}$ & $11.7 \mathrm{c}-\mathrm{e}$ & $16.6 \mathrm{a}-\mathrm{c}$ \\
\hline I-37 & 16 & $34.5 \mathrm{ab}$ & $\ldots$ & $18.8 \mathrm{c}-\mathrm{g}$ & $5.6 \mathrm{a}-\mathrm{c}$ & $2.9 \mathrm{bc}$ & $11.6 \mathrm{bc}$ & $39.0 \mathrm{a}$ & $26.2 \mathrm{ab}$ & $16.6 \mathrm{a}$ & $35.8 \mathrm{a}$ & $21.2 \mathrm{a}$ \\
\hline I-B & 17 & $5.5 \mathrm{~d}$ & $\ldots$ & $7.7 \mathrm{e}-\mathrm{h}$ & $1.7 \mathrm{bc}$ & $5.0 \mathrm{~b}$ & $10.4 \mathrm{bc}$ & $4.4 \mathrm{de}$ & $4.0 \mathrm{~cd}$ & $1.6 \mathrm{fg}$ & $25.8 \mathrm{a}-\mathrm{c}$ & $7.3 \mathrm{ef}$ \\
\hline CML 444 & 18 & $5.6 \mathrm{~d}$ & $\ldots$ & $19.5 \mathrm{c}-\mathrm{f}$ & $2.3 \mathrm{bc}$ & $1.1 \mathrm{bc}$ & $33.2 \mathrm{a}$ & $0.1 \mathrm{e}$ & $4.5 \mathrm{~cd}$ & $2.1 \mathrm{e}-\mathrm{g}$ & $1.2 \mathrm{e}$ & 7.7 ef \\
\hline R119W & 19 & $0.0 \mathrm{~d}$ & $\ldots$ & $38.6 \mathrm{a}$ & $1.8 \mathrm{bc}$ & $1.8 \mathrm{bc}$ & $22.2 \mathrm{ab}$ & $18.3 \mathrm{~b}-\mathrm{d}$ & $41.7 \mathrm{a}$ & $16.2 \mathrm{a}$ & $8.8 \mathrm{c}-\mathrm{e}$ & $16.6 \mathrm{a}-\mathrm{c}$ \\
\hline CB-222 & 20 & $5.5 \mathrm{~d}$ & $\ldots$ & $3.6 \mathrm{gh}$ & $0.1 \mathrm{c}$ & $0.3 \mathrm{c}$ & $10.8 \mathrm{bc}$ & $2.7 \mathrm{de}$ & $20.8 \mathrm{bc}$ & $6.5 \mathrm{~b}-\mathrm{g}$ & $15.6 \mathrm{~b}-\mathrm{e}$ & $7.3 \mathrm{fg}$ \\
\hline CB-248 & 21 & $11.6 \mathrm{~cd}$ & $\ldots$ & $4.1 \mathrm{f}-\mathrm{h}$ & $1.2 \mathrm{bc}$ & $2.4 \mathrm{bc}$ & $6.1 \mathrm{bc}$ & $12 \mathrm{c}-\mathrm{e}$ & $8.1 \mathrm{~b}-\mathrm{d}$ & $3.5 \mathrm{c}-\mathrm{g}$ & 3.9 ed & $5.9 \mathrm{fg}$ \\
\hline CML 390 & 22 & $3.1 \mathrm{~d}$ & $\ldots$ & $10.0 \mathrm{e}-\mathrm{h}$ & $0.5 \mathrm{bc}$ & $0.5 \mathrm{bc}$ & $19.6 \mathrm{a}-\mathrm{c}$ & $0.6 \mathrm{e}$ & $0.0 \mathrm{~d}$ & $0.2 \mathrm{~g}$ & $12.6 \mathrm{c}-\mathrm{e}$ & $5.2 \mathrm{fg}$ \\
\hline Mean & $\ldots$ & $12.5 \mathrm{~b}$ & $\ldots$ & $16.1 \mathrm{a}$ & $3.3 \mathrm{~b}$ & $3.0 \mathrm{~d}$ & $12.3 \mathrm{a}$ & $14.6 \mathrm{ab}$ & $10.8 \mathrm{a}$ & $6.3 \mathrm{c}$ & $13.9 \mathrm{a}$ & 10.3 \\
\hline LSD & $\ldots$ & 14.5 & $\ldots$ & 15.9 & 6.6 & 4.8 & 18 & 17.1 & 18.7 & 7.2 & 18 & 4.7 \\
\hline
\end{tabular}

y Mean of disease severity for three field plots indicated by the percentage of maize ears covered with visual symptoms of Fusarium ear rot. Means followed by the same letter in each column are not significantly different according to the Student's $t$ test of least significant differences (LSD, $P \geq 0.05$ ).

${ }^{\mathrm{z}}$ Combined mean. 
R119W (1.67), K64R-2 (1.10), and R2565y (1.09) exhibited inconsistent responses to FER severity across locations (Table 5).

Assessment of FER severity by GGE biplot analyses revealed that the first two PC accounted for 54.24 and $15.42 \%$, respectively, of the GGE variation (Fig. 1). The inbred lines US 2540W (\# 9), VO 617y-2 (\# 3), R2565y (\# 7), I16 (\# 5), I 37 (\# 16), I 35 (\# 10), and R119W (\# 19) delimited the polygon formed when these vertex genotypes were connected by straight lines (Fig. 1). Thus, they differed most in their response to FER across environments. Considerable crossover interactions were obtained, as demonstrated by the test localities falling into different sectors.

The maize inbred line US 2540W (\# 9) exhibited the lowest FER symptoms at Buffelsvallei and Potchefstroom in the 2010-11 season and in Vaalharts and Cedara in the 2011-12 season, to form a megaenvironment for this inbred line (Fig. 1). Inbred lines RO 424W (\# 12) and CML 390 (\# 22) also had low disease severity at the same locations and in the same years, because they fell into the same sector as US 2540W (\# 9). Inbred line VO 617y-2 (\# 3) exhibited the lowest FER symptoms at three localities (Potchefstroom 2011-12, Vaalharts 2010-11, and Cedara 2010-11), with these forming a megaenvironment for this inbred. Inbred lines CB 248 (\# 21) and RO 549W (\# 8) were also resistant to FER because they grouped close to the biplot origin and were stable in their response due to low PC1 and PC2 scores, respectively (Fig. 1; Tables 4 and 5). Inbred line R119W (\# 19) was most susceptible to FER but unstable in disease expression across locations (Fig. 1; Tables 4 and 5).

Inbred line CML 390 (\# 22; 0.47) exhibited the lowest FER severity and was the most stable in its response to the disease across localities (Fig. 2). Therefore, it was considered less affected by GEI. Other resistant genotypes which were also stable in their response to FER included inbred lines VO 617y-2 (\# 3; 0.89), US 2540W (\# 9; 0.55), RO 549W (\# 8; 0.37), RO 424W (\# 12; 0.49), and RO 544W (\# 13; 0.41). Furthermore, resistant inbred lines I-B (\# 17; $0.61)$ and CB 248 (\# 21; 0.23) were stable across localities while inbreds CML 444 (\# 18; 0.86) and CB 222 (\# 20; 0.73) differed in their disease response at various localities. Inbred lines I 34 (\# 6; 0.2), I 37 (\# 16; 0.42), and I 9 (\# 14; 0.45), however, were highly susceptible to FER yet stable in their response across environments (Fig. 2; Tables 4 and 5).

Fungal colonization. Colonization of maize kernels by $F$. verticillioides was significantly affected by genotype, environment, and GEI $(P \leq 0.05)$ (Table 3$)$. The mean FER severity is given for each locality and year of evaluation (Table 6). The GEI effect contributed the most to the total variation $(\mathrm{G}+\mathrm{E}+\mathrm{GEI})$ and explained $50.1 \%$ of the variation observed while the genotype and environment further explained 28.5 and $21.4 \%$ of the variation observed, respectively. The first and second IPCA were both significant $(P=0.00)$ and accounted for 35.9 and $21.7 \%$, respectively, of the total variation observed (Table 3). The two PCA accounted for $57.6 \%$ of the GEI variability in fungal colonization. Inbred lines K64R-2 (0.16), I-B (0.21), and CB $222(0.41)$ were the most stable in their response to $F$. verticillioides colonization across environments, while VO $617 \mathrm{y}-2$

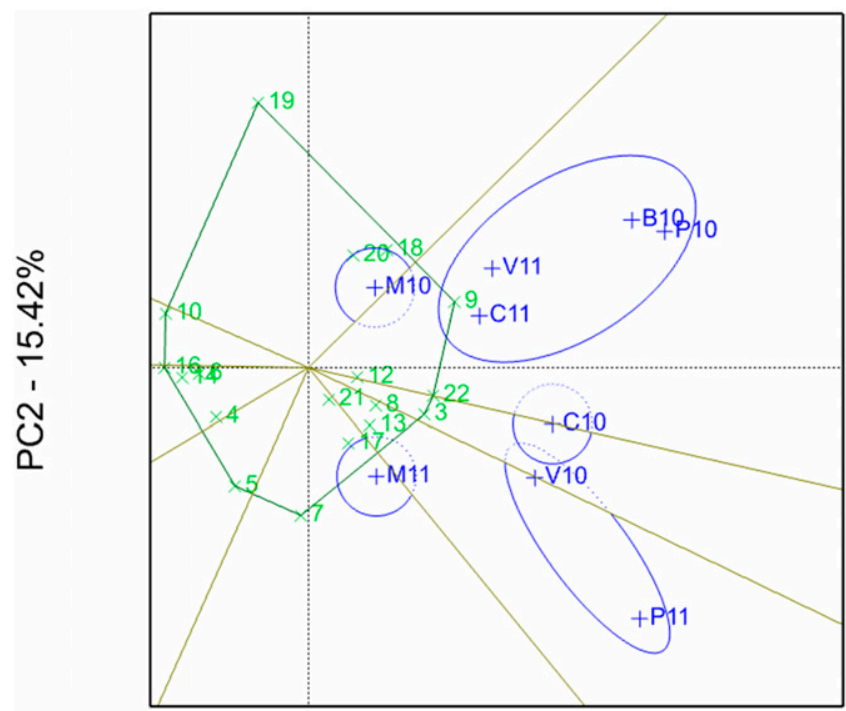

PC1 - 54.24\%

Fig. 1. Polygon view of the genotype main effect and genotype $x$ environment interaction biplot analysis for Fusarium ear rot severity based on 18 maize inbred lines evaluated during the 2010-11 and 2011-12 seasons. Numbers represent genotypes and localities are represented as Buffelsvallei 2010-11 = B10, Cedara 2010-11 and 2011-12 = C10 and C11, Makhatini 2010-11 and 2011-12 = M10 and M11, Potchefstroom 2010-11 and 2011-12 = P10 and P11, and Vaalharts 2010-11 and 2011-12 = V10 and V11. $\mathrm{PC}=$ principal component. The polygon indicates genotypes furthest from the biplot origin while sectors with ovals indicate localities that are mega-environments for the best-performing genotype. Lines starting from the origin divide the polygon into several sectors. Localities, represented by ovals, within one sector indicate where a certain genotype performed the best and can be considered as mega-environments for that genotype.

Table 5. Additive main effects and multiplicative interaction analysis stability values (ASV) and interaction principal component axes (IPCA) values for Fusarium ear rot (FER) severity, Fusarium verticillioides colonization, and total fumonisin content of maize inbred lines evaluated in South Africa

\begin{tabular}{|c|c|c|c|c|c|c|c|c|c|c|}
\hline \multirow[b]{2}{*}{ Inbred name } & \multirow[b]{2}{*}{ Line code } & \multicolumn{3}{|c|}{ FER severity } & \multicolumn{3}{|c|}{ F. verticillioides colonization } & \multicolumn{3}{|c|}{ Total fumonisins } \\
\hline & & ASV & IPCA1 & IPCA2 & ASV & IPCA1 & IPCA2 & ASV & IPCA1 & IPCA2 \\
\hline VO617y-2 & 3 & 0.89 & 0.19 & -0.86 & 2.05 & -1.21 & -0.46 & 1.66 & -0.82 & 0.13 \\
\hline K64R-2 & 4 & 1.1 & 0.31 & 1.03 & 0.16 & 0.05 & 0.14 & 1.24 & -0.62 & 0.07 \\
\hline I 16 & 5 & 0.78 & 0.64 & 0.21 & 0.64 & 0.28 & -0.44 & 0.58 & -0.01 & 0.58 \\
\hline I 34 & 6 & 0.2 & 0.06 & 0.19 & 1.2 & 0.73 & 0.06 & 1.51 & 0.73 & 0.31 \\
\hline R2565y & 7 & 1.09 & 0.77 & -0.59 & 0.61 & 0.36 & -0.13 & 0.55 & 0.27 & -0.09 \\
\hline RO 549W & 8 & 0.37 & 0.20 & 0.28 & 1.13 & -0.24 & -1.05 & 2.17 & -1.07 & -0.07 \\
\hline US 2540W & 9 & 0.55 & -0.38 & -0.31 & 1.19 & -0.71 & -0.21 & 0.76 & -0.36 & 0.21 \\
\hline I 35 & 10 & 0.74 & -0.24 & 0.68 & 1.23 & 0.74 & 0.11 & 1.44 & 0.71 & 0.02 \\
\hline RO 424W & 12 & 0.49 & 0.03 & -0.49 & 0.8 & -0.47 & -0.19 & 0.7 & -0.34 & 0.11 \\
\hline RO 544W & 13 & 0.41 & 0.30 & 0.2 & 0.83 & 0.38 & 0.53 & 0.79 & -0.37 & 0.26 \\
\hline I 9 & 14 & 0.45 & 0.08 & 0.44 & 0.84 & 0.43 & -0.45 & 1.11 & 0.45 & 0.63 \\
\hline I 37 & 16 & 0.42 & 0.04 & 0.42 & 0.85 & 0.48 & -0.31 & 0.97 & 0.42 & 0.48 \\
\hline I-B & 17 & 0.61 & 0.38 & -0.41 & 0.21 & -0.12 & -0.07 & 0.55 & 0.21 & -0.34 \\
\hline CLM 444 & 18 & 0.86 & -0.66 & -0.35 & 1.57 & -0.64 & 1.16 & 1.3 & 0.12 & -1.27 \\
\hline R119W & 19 & 1.67 & -1.40 & 0.06 & 0.64 & 0.21 & 0.54 & 0.61 & 0.26 & -0.30 \\
\hline CB 222 & 20 & 0.73 & -0.60 & -0.15 & 0.4 & 0.17 & 0.29 & 1.09 & 0.50 & -0.42 \\
\hline CB 248 & 21 & 0.23 & 0.17 & 0.10 & 0.54 & 0.32 & 0.07 & 0.61 & 0.30 & 0.00 \\
\hline CML 390 & 22 & 0.47 & 0.11 & -0.45 & 1.35 & -0.08 & 0.41 & 0.84 & -0.39 & -0.31 \\
\hline Mean & $\ldots$ & 0.6 & $\ldots$ & $\ldots$ & 0.77 & $\ldots$ & $\ldots$ & 0.91 & $\ldots$ & $\cdots$ \\
\hline
\end{tabular}


(2.05), CML $444(-0.64)$, and CML 390 (-0.08) were inconsistent in their response (Table 5). Visualization of fungal colonization by GGE biplot analyses accounted for $67.9 \%$ (PC1, 53.8\% and PC2, 14.1\%) of the total GGE variation. The inbred lines VO 617y-2 (\# 3), CML 390 (\# 22), CML 444 (\# 18), R119W (\# 19), I 35 (\# 10), I 16 (\# 5), and RO 549W (\# 8) differed the most in their response to $F$. verticillioides colonization and outlined the polygon (Fig. 3). Test localities fell into different sectors, indicating significant crossover interaction. The inbred line VO 617y-2 (\# 3) accumulated the lowest fungal target DNA at Buffelsvallei during the 2010-11 season and at Potchefstroom, Vaalharts, and Cedara during the 2011-12 season, forming a megaenvironment (Fig. 3). Inbred lines RO 424W (\# 12) and US 2540W (\# 9) also resisted fungal colonization at the same localities and grouped with inbred line VO 617y-2 (\# 3) into the same sector (Fig. 3).

Inbred line CML 390 (\# 22) was resistant $\left(0.04 \mathrm{ng} \mu \mathrm{l}^{-1}\right)$ to fungal colonization in multiple environments over the two seasons (Makhatini in 2010-11 and 2011-12 and Vaalharts, Cedara, and Potchefstroom in 2010-11) to form a second mega-environment (Fig. 3). Furthermore, inbred lines CB 222 (\# 20;0.40), RO 424W (\# 12;0.80), and US 2540W (\# 9; 1.19) were also resistant to $F$. verticillioides colonization but were unstable in their response to fungal colonization across locations. Inbred lines R119W (\# 19; 0.64), I 16 (\# 5; 0.64), I 35 (\# 10; 1.23 ), and I 9 (\# 14; 0.84) were consistently susceptible to $F$. verticillioides colonization across environments (Fig. 3; Tables 5 and 6).

Overall, inbred line CML 390 (\# 22) was the most resistant to $F$. verticillioides colonization and most stable in its response across locations (Fig. 4). Inbred lines US 2540W (\# 9) and RO 424W (\# 12) were also resistant to $F$. verticillioides colonization based on their proximity to the AEC. Inbred lines R119W (\# 19), I 35 (\# 10), I 34 (\# 6), I 16 (\# 5), and I 9 (\# 14) were most susceptible to $F$. verticillioides colonization across locations (Fig. 4; Table 6).

Fumonisin accumulation. Environment, genotype, and GEI $(P \leq$ $0.05)$ significantly affected the total fumonisins that accumulated in the grain of the maize inbred lines (Table 3). The environment effect was responsible for the largest variation in fumonisin accumulation and explained $43.7 \%$ of the total variation $(\mathrm{G}+\mathrm{E}+\mathrm{GEI})$. GEI and genotype each contributed 32.0 and $10.9 \%$, respectively, to the variation in

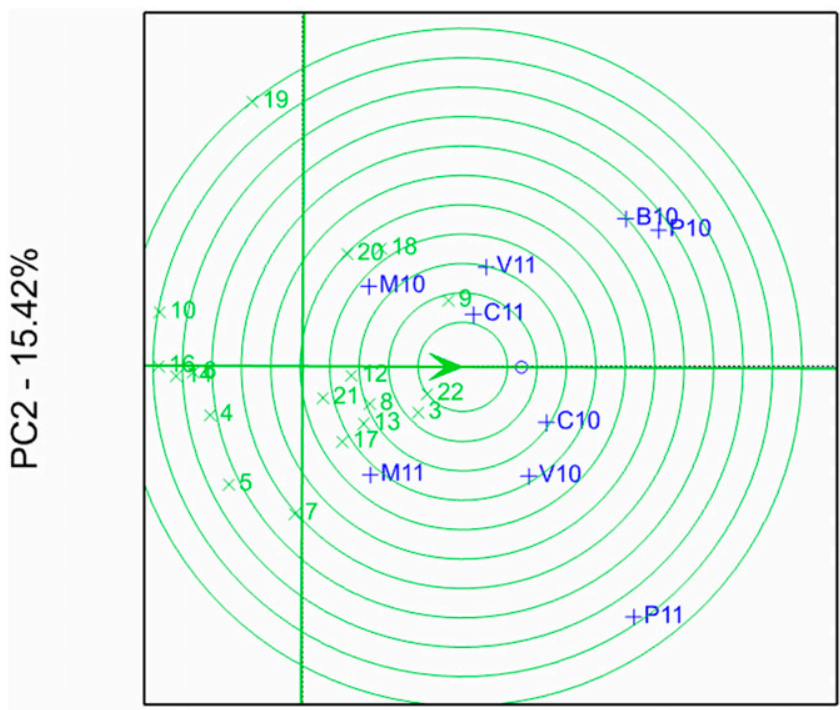

PC1 $-54.24 \%$

Fig. 2. Genotype main effect and genotype $\times$ environment interaction biplot based on environment-focused scaling for comparison of genotypes for Fusarium ear rot severity in 18 maize inbred lines tested during the 2010-11 and 2011-12 seasons. Numbers represent genotypes and localities are represented as Buffelsvallei 2010-11 = B10, Cedara 2010-11 and 2011-12 = C10 and C11, Makhatini 2010-11 and 2011-12 = M10 and M11, Potchefstroom 2010-11 and 2011-12 = P10 and P11, and Vaalharts 2010-11 and 2011-12 = V10 and V11. The circle represents the average principal components $(P C)$ in all environments while distances between genotypes and the ideal genotype are indicated by concentric circles. fumonisin accumulation. IPCA 1 and IPCA 2 were both significant and explained 42.71 and $21.19 \%$, respectively, of the total variation (Table 3 ), while they accounted for $63.9 \%$ of the total treatment variability in fumonisin accumulation. Therefore, the total mean fumonisin accumulation of each inbred line for each locality and year of evaluation was analyzed (Table 7). The stability of inbred line response to fumonisin accumulation across environments as determined by ASV ranged from 0.55 to 2.17 (Table 3). Inbred lines R2565y (0.55), I-B (0.55), and I 16 (0.58) were the most stable in their response, while RO 549W (2.17), VO 617y-2 (1.66), and I 34 (1.51) were the most inconsistent (Table 5).

A total of $63.3 \%$ (PC1, 44.3\% and PC2, 19.0\%) of the GGE variation was visualized by the biplot (Fig. 5). Inbred line CML 390 (\# 22) exhibited the lowest fumonisin accumulation in all localities across 2 years, creating a single mega-environment. The locations had crossover interactions, as demonstrated by their division into different sectors of the polygon view (Fig. 5). Inbred lines RO 424W (\# 12) and US 2540W (\# 9) also exhibited resistance to fumonisin accumulation across localities and occupied the same sector as inbred line CML 390 (Fig. 5). Furthermore, inbred lines RO 424W (0.70) and US 2540W (0.76) were stable in their response to fumonisin accumulation (Table 5). Inbred lines I 16 (\# 5; 0.58), I 9 (\# 14; 1.11), R119W (\# 19; 0.61), I 35 (\# 10; 1.44), and I 34 (\# 6; 1.51) were most susceptible to fumonisin accumulation and differed in the stability of their response (Fig. 5; Tables 5 and 7).

Inbred line CML 390 (\# 22) was the most resistant $\left(4.1 \mathrm{mg} \mathrm{kg}^{-1}\right)$ to fumonisin accumulation and stable in its response across locations (Fig. 6). Inbred lines US 2540W (\# 9) and RO 424W (\# 12) were also resistant based on their proximity to the AEC. Inbred lines R119W (\# 19), I 35 (\# 10), I 34 (\# 6), I 16 (\# 5), and I 9 (\# 14) were most susceptible to fumonisin accumulation (Fig. 6; Table 7).

Correlations between FER severity, $F$. verticillioides colonization, and fumonisin contamination. Significant correlations between FER severity, fungal colonization, and fumonisin accumulation were observed at all localities in both seasons (Table 8). In 2010-11, moderate correlations between FER and $F$. verticillioides colonization were determined at Buffelsvallei $(R=0.57)$ and Potchefstroom $(R=0.57)$

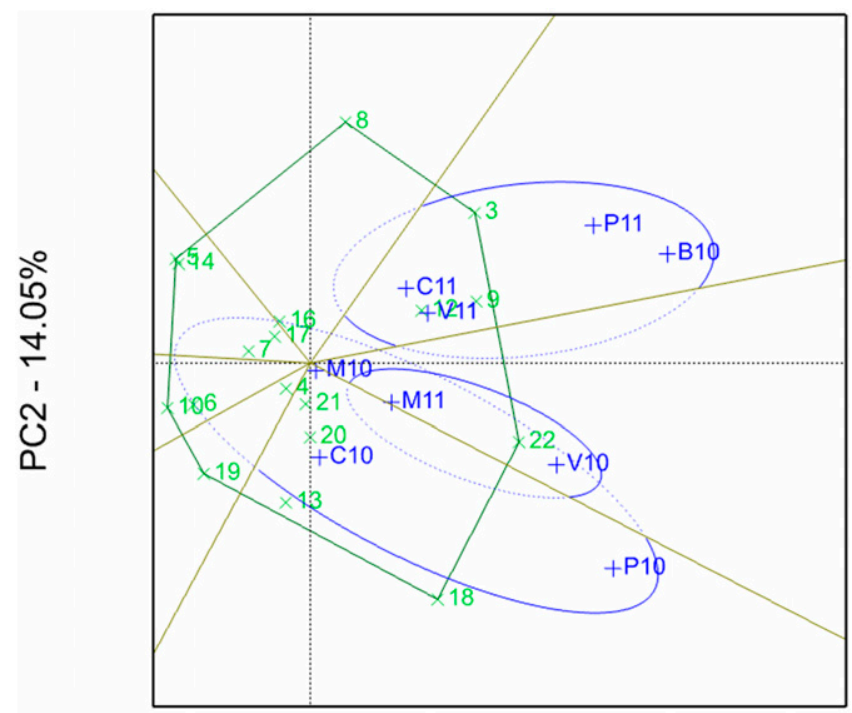

PC1 $-53.80 \%$

Fig. 3. Polygon view of the genotype main effect and genotype $\times$ environment interaction biplot analysis of Fusarium verticillioides colonization based on 18 maize inbred lines evaluated during the 2010-11 and 2011-12 seasons. Numbers represent genotypes and localities are represented as Buffelsvallei 2010-11 = B10, Cedara 2010-11 and 2011-12 = C10 and C11, Makhatini 2010-11 and 2011-12 = M10 and M11, Potchefstroom 2010-11 and 2011-12 = P10 and P11, and Vaalharts 2010-11 and 2011-12 = V10 and V11 $\mathrm{PC}=$ principal component. The polygon indicates genotypes furthest from the biplot origin while sectors with ovals indicate localities that are mega-environments for the bestperforming genotype. Lines starting from the origin divide the polygon into several sectors. Localities, represented by ovals, within one sector indicate where a certain genotype performed the best and can be considered as mega-environments for that genotype. 
while a poor though significant correlation was determined at Cedara $(R=0.32)$. Insignificant correlations were observed at Makhatini $(R=0.24, P=0.0750)$ and Vaalharts $(R=0.19, P=0.1733)$. The relationship between FER and total fumonisin content was insignificant at four of the five localities planted in 2010-11, with a moderate correlation between these parameters determined only at Potchefstroom $(R=0.56)$. Conversely, moderate to strong positive correlations were determined between $F$. verticillioides colonization and total fumonisin content of grain from maize inbred lines at all localities during 2010-11 (Table 8).

In 2011-12, poor though significant correlations were determined between FER and fungal content in grain at Cedara $(R=0.41)$ and Vaalharts $(R=0.36)$ while insignificant correlations were established for Makhatini $(R=0.12, P=0.3754)$ and Potchefstroom $(R=0.26$, $P=0.0596)$ (Table 8). The correlations between FER and fumonisin content at Makhatini $(R=0.29)$, Potchefstroom $(R=0.40)$, and Vaalharts $(R=0.36)$ were significantly poor and insignificant at Cedara $(R=0.25$, $P=0.0735)$. Moderate to strong positive correlations were again determined between $F$. verticillioides colonization and total fumonisin content of grain from maize inbred lines at all localities during the 2011-12 season (Table 8).

Over the two seasons, the correlation between FER and $F$. verticillioides colonization at Cedara $(R=0.47)$, Makhatini $(R=0.30)$, and Potchefstroom $(R=0.39)$ was significantly moderate to poor and insignificant at Vaalharts $(R=0.09, P=0.3356)$. The association between FER and fumonisin content in maize grain was significantly moderate at Cedara $(R=0.40)$, Makhatini $(R=0.45)$, and Potchefstroom $(R=0.46)$ and insignificant at Vaalharts $(R=0.10, P=$ 0.3076). Strong positive correlations between fungal and fumonisin content of maize grain were observed at all localities evaluated over the two seasons (Table 8). In the overall study, FER and $F$. verticillioides colonization $(R=0.36)$ as well as FER and fumonisin content ( $R=0.31$ ) correlated poorly while $F$. verticillioides colonization and total fumonisins correlated well $(R=0.64)$.

\section{Discussion}

Maize cultivars grown in South Africa are highly susceptible to FER and fumonisin contamination, with fumonisin levels often exceeding the tolerable limits enforced in Europe and the United States
(Janse van Rensburg et al. 2015; Rheeder et al. 1990). Therefore, sources of resistance to $F$. verticillioides and fumonisin accumulation are urgently needed to develop resistant cultivars for use in commercial and subsistence farming systems. In this study, maize inbred

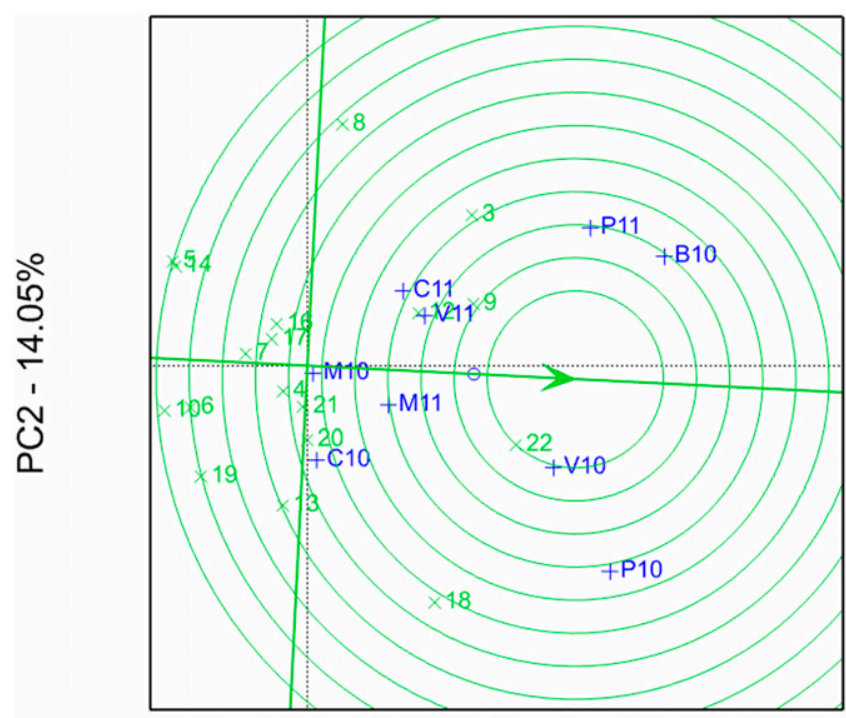

\section{PC1 - 53.80\%}

Fig. 4. Genotype main effect and genotype $\times$ environment interaction biplot based on environment-focused scaling for comparison of genotypes for Fusarium verticillioides colonization in 18 maize evaluated during the 2010-11 and 2011-12 seasons. Numbers represent genotypes and localities are represented as Buffelsvallei 2010-11 = B10, Cedara 2010-11 and 2011-12 = C10 and C11, Makhatini 2010-11 and 2011-12 = M10 and M11, Potchefstroom 2010-11 and 2011-12 = P10 and P11, and Vaalharts 2010-11 and 2011-12 = V10 and V11. The circle represents the average principal components (PC) in all environments while distances between genotypes and the ideal genotype are indicated by concentric circles.

Table 6. Fusarium verticillioides colonization of maize inbred lines planted at multiple field locations in South Africa during the 2010-11 and 2011-12 maize-growing seasons

\begin{tabular}{|c|c|c|c|c|c|c|c|c|c|c|c|c|}
\hline \multirow[b]{3}{*}{ Inbred name } & \multirow[b]{3}{*}{ Code $^{y}$} & \multicolumn{11}{|c|}{ F. verticillioides target DNA $\left(\mathrm{ng} \mu \mathrm{I}^{-1}\right)^{\mathrm{x}}$} \\
\hline & & \multicolumn{2}{|c|}{ Buffelsvallei } & \multicolumn{2}{|c|}{ Cedara } & \multicolumn{2}{|c|}{ Makhatini } & \multicolumn{2}{|c|}{ Potchefstroom } & \multicolumn{2}{|c|}{ Vaalharts } & \multirow[b]{2}{*}{ Combined $^{\mathrm{z}}$} \\
\hline & & 2010-11 & 2011-12 & 2010-11 & 2011-12 & 2010-11 & 2011-12 & 2010-11 & 2011-12 & 2010-11 & 2011-12 & \\
\hline VO $617 y-2$ & 3 & $0.02 \mathrm{~d}$ & $\ldots$ & $0.33 \mathrm{a}$ & $0.02 \mathrm{c}$ & $0.13 \mathrm{a}$ & $0.18 \mathrm{c}-\mathrm{g}$ & $0.03 \mathrm{~d}$ & $0.01 \mathrm{~d}$ & $0.05 \mathrm{~d}-\mathrm{e}$ & $0.05 \mathrm{~b}-\mathrm{d}$ & $0.09 \mathrm{~d}-\mathrm{f}$ \\
\hline K64R-22 & 4 & $0.15 \mathrm{~cd}$ & $\ldots$ & $0.18 \mathrm{a}-\mathrm{f}$ & $0.88 \mathrm{a}-\mathrm{c}$ & $0.09 \mathrm{ab}$ & $0.17 \mathrm{~d}-\mathrm{g}$ & $0.05 \mathrm{~d}$ & $0.25 \mathrm{a}-\mathrm{c}$ & $0.11 \mathrm{c}-\mathrm{f}$ & $0.01 \mathrm{~d}$ & $0.12 \mathrm{c}-\mathrm{e}$ \\
\hline $\mathrm{I}-16$ & 5 & $0.48 \mathrm{a}-\mathrm{c}$ & $\ldots$ & $0.29 \mathrm{ab}$ & $0.15 \mathrm{a}$ & $0.09 \mathrm{ab}$ & $0.56 \mathrm{a}$ & $0.30 \mathrm{ab}$ & $0.12 \mathrm{~b}-\mathrm{d}$ & $0.37 \mathrm{a}$ & $0.13 \mathrm{ab}$ & $0.28 \mathrm{a}$ \\
\hline I-34 & 6 & $0.20 \mathrm{~cd}$ & $\ldots$ & $0.04 \mathrm{f}$ & $0.07 \mathrm{a}-\mathrm{c}$ & $0.11 \mathrm{a}$ & $0.25 \mathrm{~cd}$ & $0.16 \mathrm{~b}-\mathrm{d}$ & $0.31 \mathrm{ab}$ & $0.23 \mathrm{bc}$ & 0.04 b-d & $0.16 b c$ \\
\hline R2565y & 7 & $0.16 \mathrm{~cd}$ & $\ldots$ & $0.15 \mathrm{~b}-\mathrm{f}$ & $0.02 \mathrm{c}$ & $0.08 \mathrm{ab}$ & $0.14 \mathrm{~d}-\mathrm{g}$ & $0.13 \mathrm{~b}-\mathrm{d}$ & $0.20 \mathrm{~b}-\mathrm{d}$ & $0.10 \mathrm{c}-\mathrm{f}$ & $0.15 \mathrm{a}$ & $0.13 \mathrm{c}-\mathrm{e}$ \\
\hline RO 549W & 8 & $0.02 \mathrm{~d}$ & $\ldots$ & $0.28 \mathrm{a}-\mathrm{c}$ & $0.02 \mathrm{c}$ & $0.08 \mathrm{ab}$ & $0.08 \mathrm{~g}$ & $0.14 \mathrm{~b}-\mathrm{d}$ & $0.03 \mathrm{~cd}$ & $0.31 \mathrm{ab}$ & $0.03 \mathrm{~cd}$ & $0.11 \mathrm{c}-\mathrm{e}$ \\
\hline US 2540 & 9 & $0.01 \mathrm{~d}$ & $\ldots$ & $0.06 \mathrm{f}$ & $0.03 \mathrm{c}$ & $0.10 \mathrm{ab}$ & $0.33 \mathrm{bc}$ & $0.02 \mathrm{~d}$ & $0.02 \mathrm{~cd}$ & $0.05 \mathrm{~d}-\mathrm{f}$ & $0.02 \mathrm{~d}$ & 0.07 ef \\
\hline $\mathrm{I}-35$ & 10 & $0.87 \mathrm{a}$ & $\ldots$ & $0.10 \mathrm{~d}-\mathrm{f}$ & $0.05 \mathrm{a}-\mathrm{c}$ & $0.09 \mathrm{ab}$ & $0.13 \mathrm{~d}-\mathrm{g}$ & $0.28 \mathrm{a}-\mathrm{c}$ & $0.43 \mathrm{a}$ & $0.40 \mathrm{a}$ & $0.09 \mathrm{a}-\mathrm{d}$ & $0.27 \mathrm{a}$ \\
\hline RO 424W & 12 & $0.04 \mathrm{~cd}$ & $\ldots$ & $0.13 \mathrm{c}-\mathrm{f}$ & $0.05 \mathrm{bc}$ & $0.06 \mathrm{ab}$ & $0.12 \mathrm{~d}-\mathrm{g}$ & $0.05 \mathrm{~d}$ & $0.02 \mathrm{~cd}$ & $0.03 \mathrm{ef}$ & $0.04 \mathrm{~b}-\mathrm{d}$ & 0.06 ef \\
\hline RO $544 W$ & 13 & $0.26 \mathrm{~b}-\mathrm{d}$ & $\ldots$ & $0.12 \mathrm{c}-\mathrm{f}$ & $0.04 \mathrm{c}$ & $0.06 \mathrm{ab}$ & $0.10 \mathrm{e}-\mathrm{g}$ & $0.05 \mathrm{~d}$ & $0.16 \mathrm{~b}-\mathrm{d}$ & $0.03 \mathrm{ef}$ & $0.08 \mathrm{a}-\mathrm{d}$ & $0.99 \mathrm{c}-\mathrm{f}$ \\
\hline I-9 & 14 & $0.67 \mathrm{ab}$ & $\ldots$ & $0.23 \mathrm{a}-\mathrm{e}$ & $0.08 \mathrm{a}-\mathrm{c}$ & $0.11 \mathrm{ab}$ & $0.47 \mathrm{ab}$ & $0.41 \mathrm{a}$ & $0.11 \mathrm{~b}-\mathrm{d}$ & $0.17 \mathrm{~cd}$ & $0.02 \mathrm{~d}$ & $0.25 \mathrm{a}$ \\
\hline $\mathrm{I}-37$ & 16 & $0.21 \mathrm{~cd}$ & $\ldots$ & 0.08 ef & $0.03 \mathrm{c}$ & $0.02 \mathrm{~b}$ & $0.23 \mathrm{c}-\mathrm{f}$ & $0.13 \mathrm{~b}-\mathrm{d}$ & $0.04 \mathrm{~cd}$ & $0.12 \mathrm{c}-\mathrm{f}$ & $0.06 \mathrm{~b}-\mathrm{d}$ & $0.10 \mathrm{c}-\mathrm{f}$ \\
\hline I-B & 17 & $0.07 \mathrm{~cd}$ & $\ldots$ & $0.12 \mathrm{c}-\mathrm{f}$ & $0.04 \mathrm{bc}$ & $0.11 \mathrm{a}$ & $0.56 \mathrm{a}$ & $0.07 \mathrm{~d}$ & $0.09 \mathrm{~b}-\mathrm{d}$ & $0.16 \mathrm{~cd}$ & $0.13 a b$ & $0.15 \mathrm{~b}-\mathrm{d}$ \\
\hline CML 444 & 18 & $0.04 \mathrm{~cd}$ & $\ldots$ & 0.08 ef & $0.13 \mathrm{ab}$ & $0.06 \mathrm{ab}$ & $0.13 \mathrm{~d}-\mathrm{g}$ & $0.00 \mathrm{~d}$ & $0.07 \mathrm{~cd}$ & $0.05 \mathrm{~d}-\mathrm{f}$ & $0.04 \mathrm{~b}-\mathrm{d}$ & $0.07 \mathrm{ef}$ \\
\hline R119W & 19 & $0.81 \mathrm{a}$ & $\ldots$ & $0.27 \mathrm{a}-\mathrm{d}$ & $0.08 \mathrm{a}-\mathrm{c}$ & $0.11 \mathrm{a}$ & $0.25 \mathrm{c}-\mathrm{e}$ & $0.06 \mathrm{~d}$ & $0.13 \mathrm{~b}-\mathrm{d}$ & $0.12 \mathrm{c}-\mathrm{f}$ & $0.12 \mathrm{a}-\mathrm{c}$ & $0.22 \mathrm{ab}$ \\
\hline CB-222 & 20 & $0.16 \mathrm{~cd}$ & $\ldots$ & 0.10 ef & $0.02 \mathrm{c}$ & $0.06 \mathrm{ab}$ & $0.11 \mathrm{~d}-\mathrm{g}$ & $0.02 \mathrm{~d}$ & $0.09 \mathrm{~b}-\mathrm{d}$ & $0.18 \mathrm{~b}-\mathrm{d}$ & $0.08 \mathrm{a}-\mathrm{d}$ & $0.09 \mathrm{c}-\mathrm{f}$ \\
\hline CB-248 & 21 & $0.19 \mathrm{~cd}$ & $\ldots$ & $0.06 \mathrm{f}$ & $0.03 \mathrm{c}$ & $0.09 \mathrm{ab}$ & $0.16 \mathrm{~d}-\mathrm{g}$ & $0.09 \mathrm{~cd}$ & $0.06 \mathrm{~cd}$ & $0.07 \mathrm{~d}-\mathrm{f}$ & $0.16 \mathrm{a}$ & $0.10 \mathrm{c}-\mathrm{f}$ \\
\hline CML 390 & 22 & $0.03 \mathrm{~cd}$ & $\ldots$ & 0.09 ef & $0.03 \mathrm{c}$ & $0.09 \mathrm{ab}$ & $0.09 \mathrm{fg}$ & $0.01 \mathrm{~d}$ & $0.01 \mathrm{~d}$ & $0.01 \mathrm{f}$ & $0.03 \mathrm{~cd}$ & $0.04 \mathrm{f}$ \\
\hline Mean & $\ldots$ & $0.24 \mathrm{a}$ & $\ldots$ & $0.15 \mathrm{~b}$ & $0.06 \mathrm{c}$ & $0.09 \mathrm{c}$ & $0.23 \mathrm{a}$ & $0.11 \mathrm{bc}$ & $0.12 \mathrm{~b}$ & $0.14 \mathrm{bc}$ & $0.07 \mathrm{c}$ & 0.18 \\
\hline LSD & $\ldots$ & 0.45 & $\ldots$ & 0.17 & 0.1 & 0.09 & 0.15 & 0.21 & 0.23 & 0.14 & 0.09 & 0.07 \\
\hline
\end{tabular}

${ }^{\mathrm{x}}$ Means of absolute concentrations of $F$. verticillioides DNA for three field plots, with each field plot represented by the average of two technical replications for quantitative polymerase chain reaction; mean of fungal target DNA for three field plots. Means followed by the same letter in each column are not significantly different according to the Student's $t$ test of least significant differences (LSD, $P \geq 0.05$ ).

${ }^{y}$ Line code.

${ }^{\mathrm{z}}$ Combined mean. 
lines CML 390, US 2540W, and RO 424W were identified as resis-

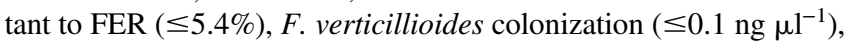
and fumonisin accumulation ( $\leq 5.6 \mathrm{ppm}$ ) across different environments. Resistance to FER and fumonisin accumulation by CML

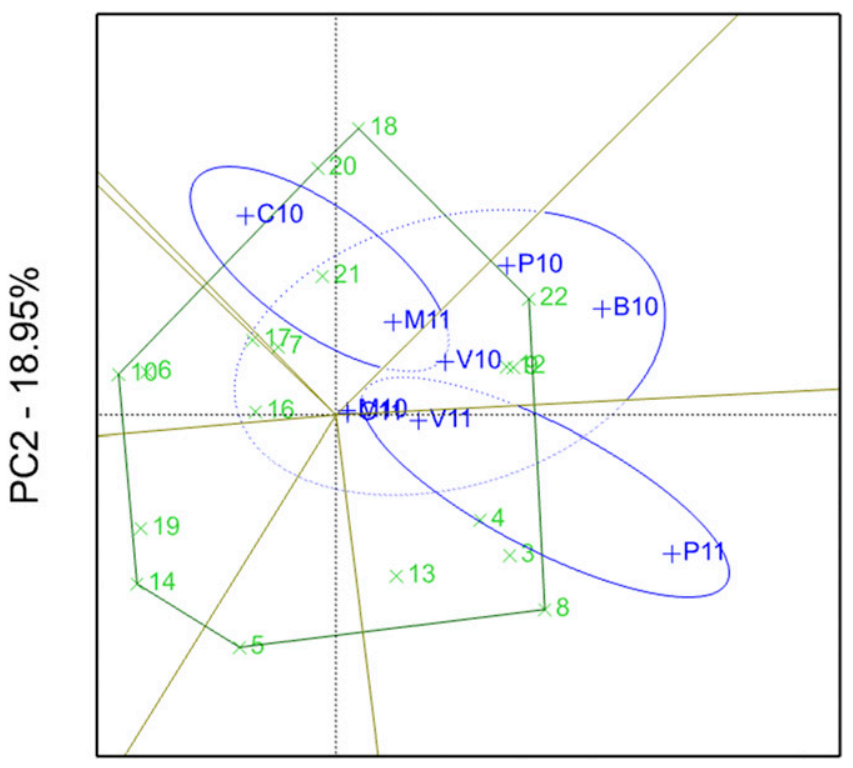

PC1 - 44.34\%

Fig. 5. Polygon view of the genotype main effect and genotype $x$ environment interaction biplot analysis of total fumonisin accumulation in 18 maize inbred lines evaluated during the 2010-11 and 2011-12 seasons. Numbers represent genotypes and localities are represented as Buffelsvallei 2010-11 = B10, Cedara 2010-11 and 2011-12 = C10 and C11, Makhatini 2010-11 and 2011-12 = M10 and M11, Potchefstroom 2010-11 and 2011-12 = P10 and P11, and Vaalharts 2010-11 and 2011-12 = V10 and V11. PC = principal component. The polygon indicates genotypes furthest from the biplot origin while sectors with ovals indicate localities that are mega-environments for the best-performing genotype. Lines starting from the origin divide the polygon into several sectors. Localities, represented by ovals, within one sector indicate where a certain genotype performed the best and can be considered as mega-environments for that genotype.
390 has previously been reported (Small et al. 2012). The resistant inbred lines identified in this study could potentially be used in plant improvement programs to reduce the risk of fumonisin contamination in the country.

Inbred lines VO $617 \mathrm{y}-2$ and RO 549W, although resistant to FER and fungal colonization across environments, were less resistant to fumonisin accumulation, with both exceeding the overall mean fumonisin content. Inbred line RO 544W exhibited resistance to FER and was susceptible to fungal colonization, yet contained fumonisins below the overall mean. Lines K64R22, R2565y, and I-37 were susceptible to FER but contained fungal and fumonisin levels that did not differ significantly from resistant lines or were less than the overall mean. These results suggests that the genetic potential for resistance to FER (disease expression), fungal colonization, and fumonisin accumulation may exist independently of each other and are determined by the maize genotype. QTL associated with resistance to FER and fumonisin accumulation have been documented as well as QTL uniquely associated with each of these traits (Robertson-Hoyt et al. 2006, 2007). Inbred lines susceptible to FER yet resistant to fumonisin contamination could be used to identify QTL specifically associated with resistance to fumonisin accumulation.

A significant GEI was observed for all the inbred lines evaluated in this study. The GEI contributed more to the variation in FER severity and $F$. verticillioides colonization than to fumonisin production, while the environment contributed largely to the variation in fumonisin accumulation. These results highlight the ability to screen for resistance to FER and $F$. verticillioides colonization in environments that are conducive to the proliferation of the fungus, while the suitability of an environment for evaluating resistance to fumonisin accumulation should first be established. Differential response of inbred lines to FER and fumonisin accumulation due to GEI has been documented previously (Afolabi et al. 2007; Clements et al. 2004; Small et al. 2012). Additionally, fumonisin contamination was shown to be predominantly affected by the prevailing environmental conditions (Cao et al. 2014). This was also observed by de la Campa et al. (2005) when modeling the effects of environment, insect damage, and $B t$ genotypes on fumonisin accumulation. The strong influence of environment on fumonisin accumulation accentuates the value of evaluating resistance to fumonisin accumulation in target environments.

Significant differences in climatic data between localities contributed to the GEI effect observed in this study. Furthermore, maximum

Table 7. Total fumonisin content of maize inbred lines planted at multiple field locations in South Africa during the 2010-11 and 2011-12 maize-growing seasons

\begin{tabular}{|c|c|c|c|c|c|c|c|c|c|c|c|c|}
\hline \multirow[b]{3}{*}{ Inbred name } & \multirow[b]{3}{*}{ Line code } & \multicolumn{11}{|c|}{ Total fumonisins $\left(\mathrm{mg} \mathrm{kg}^{-1}\right)^{y}$} \\
\hline & & \multicolumn{2}{|c|}{ Buffelsvallei } & \multicolumn{2}{|c|}{ Cedara } & \multicolumn{2}{|c|}{ Makhatini } & \multicolumn{2}{|c|}{ Potchefstroom } & \multicolumn{2}{|c|}{ Vaalharts } & \multirow[b]{2}{*}{ Combined $^{\mathrm{z}}$} \\
\hline & & $2010-11$ & $2011-12$ & $2010-11$ & $\overline{2011-12}$ & $2010-11$ & $\overline{2011-12}$ & $2010-11$ & $\overline{2011-12}$ & $2010-11$ & $\overline{2011-12}$ & \\
\hline VO $617 y-2$ & 3 & $1.9 \mathrm{~g}$ & $\ldots$ & $35.6 \mathrm{~b}$ & $1.7 \mathrm{~d}$ & $5.1 \mathrm{a}-\mathrm{c}$ & $25.7 \mathrm{a}-\mathrm{f}$ & $5.7 \mathrm{~cd}$ & $0.0 \mathrm{e}$ & $5.2 \mathrm{~d}$ & $4.4 \mathrm{ab}$ & $9.5 \mathrm{~d}-\mathrm{f}$ \\
\hline K64R-22 & 4 & $4.8 \mathrm{gf}$ & $\ldots$ & $22.8 \mathrm{~cd}$ & $3.2 \mathrm{~b}-\mathrm{d}$ & $5.0 \mathrm{a}-\mathrm{c}$ & $15.2 \mathrm{~d}-\mathrm{g}$ & $4.3 \mathrm{~cd}$ & $0.0 \mathrm{e}$ & $7.7 \mathrm{~cd}$ & $0.9 \mathrm{e}$ & $7.1 \mathrm{e}-\mathrm{i}$ \\
\hline $\mathrm{I}-16$ & 5 & $18.6 \mathrm{~cd}$ & $\ldots$ & $18.6 \mathrm{de}$ & $5.5 \mathrm{bc}$ & $0.7 \mathrm{c}$ & $31.1 \mathrm{a}-\mathrm{c}$ & $25.7 \mathrm{a}-\mathrm{c}$ & $2.1 \mathrm{de}$ & $27.7 \mathrm{a}$ & $5.2 \mathrm{a}$ & $15.0 \mathrm{ab}$ \\
\hline $\mathrm{I}-34$ & 6 & $18.6 \mathrm{~cd}$ & $\ldots$ & $3.8 \mathrm{~g}$ & $1.7 \mathrm{~d}$ & $5.8 \mathrm{a}-\mathrm{c}$ & $27.9 \mathrm{a}-\mathrm{d}$ & $15.2 \mathrm{a}-\mathrm{d}$ & $7.7 \mathrm{bc}$ & $10.4 \mathrm{~cd}$ & $3.1 \mathrm{a}-\mathrm{e}$ & $10.5 \mathrm{c}-\mathrm{e}$ \\
\hline R2565y & 7 & $4.8 \mathrm{gf}$ & $\ldots$ & $13.3 \mathrm{~d}-\mathrm{g}$ & $0.9 \mathrm{~d}$ & $3.9 \mathrm{a}-\mathrm{c}$ & $15.9 \mathrm{c}-\mathrm{g}$ & $7.5 \mathrm{~cd}$ & $7.9 \mathrm{bc}$ & $9.6 \mathrm{~cd}$ & $2.7 \mathrm{~b}-\mathrm{e}$ & $7.4 \mathrm{e}-\mathrm{i}$ \\
\hline RO 549W & 8 & $1.5 \mathrm{~g}$ & $\ldots$ & $74.4 \mathrm{a}$ & $4.1 \mathrm{~b}-\mathrm{d}$ & $4.7 \mathrm{a}-\mathrm{c}$ & $10.9 \mathrm{gf}$ & $5.9 \mathrm{~cd}$ & $0.0 \mathrm{e}$ & $13.6 \mathrm{~b}-\mathrm{d}$ & $1.0 \mathrm{de}$ & $12.9 \mathrm{~b}-\mathrm{d}$ \\
\hline US 2540 & 9 & $1.7 \mathrm{~g}$ & $\ldots$ & $7.0 \mathrm{gf}$ & $0.6 \mathrm{~d}$ & $4.0 \mathrm{a}-\mathrm{c}$ & $26.8 \mathrm{a}-\mathrm{e}$ & $4.1 \mathrm{~cd}$ & $0.0 \mathrm{e}$ & $5.0 \mathrm{~d}$ & $1.3 \mathrm{de}$ & $5.6 \mathrm{~g}-\mathrm{i}$ \\
\hline $\mathrm{I}-35$ & 10 & $13.4 \mathrm{de}$ & $\ldots$ & $8.7 \mathrm{e}-\mathrm{g}$ & $1.9 \mathrm{~cd}$ & $5.8 \mathrm{a}-\mathrm{c}$ & $10.9 \mathrm{gf}$ & $37.0 \mathrm{a}$ & $17.6 \mathrm{e}$ & $23.9 \mathrm{ab}$ & $3.1 \mathrm{a}-\mathrm{e}$ & $13.6 \mathrm{a}-\mathrm{c}$ \\
\hline RO 424W & 12 & $2.7 \mathrm{~g}$ & $\ldots$ & $9.1 \mathrm{e}-\mathrm{g}$ & $2.1 \mathrm{~cd}$ & $2.9 \mathrm{bc}$ & $10.8 \mathrm{gf}$ & $4.0 \mathrm{~cd}$ & $0.0 \mathrm{e}$ & $4.2 \mathrm{~d}$ & $1.8 \mathrm{c}-\mathrm{e}$ & $4.2 \mathrm{i}$ \\
\hline RO 544W & 13 & $24.5 \mathrm{c}$ & $\ldots$ & $20.1 \mathrm{~d}$ & $2.7 \mathrm{~b}-\mathrm{d}$ & $5.1 \mathrm{a}-\mathrm{c}$ & $17.2 \mathrm{~b}-\mathrm{g}$ & $3.8 \mathrm{~cd}$ & $0.0 \mathrm{e}$ & $4.1 \mathrm{~d}$ & $2.0 \mathrm{c}-\mathrm{e}$ & $8.8 \mathrm{e}-\mathrm{g}$ \\
\hline I-9 & 14 & $33.3 \mathrm{~b}$ & $\ldots$ & $15.2 \mathrm{~d}-\mathrm{f}$ & $2.7 \mathrm{~b}-\mathrm{d}$ & $9.1 \mathrm{a}$ & $25.9 \mathrm{a}-\mathrm{f}$ & $33.8 \mathrm{ab}$ & $6.1 \mathrm{~b}-\mathrm{d}$ & $9.4 \mathrm{~cd}$ & $1.8 \mathrm{c}-\mathrm{e}$ & $15.3 \mathrm{ab}$ \\
\hline $\mathrm{I}-37$ & 16 & $12.2 \mathrm{de}$ & $\ldots$ & $6.8 \mathrm{gf}$ & $3.4 \mathrm{~b}-\mathrm{d}$ & $2.0 \mathrm{c}$ & $13.8 \mathrm{~d}-\mathrm{g}$ & $24.2 \mathrm{a}-\mathrm{d}$ & $3.8 \mathrm{c}-\mathrm{e}$ & $7.5 \mathrm{~cd}$ & $2.8 \mathrm{~b}-\mathrm{e}$ & $8.5 \mathrm{e}-\mathrm{h}$ \\
\hline I-B & 17 & $5.5 \mathrm{e}-\mathrm{g}$ & $\ldots$ & $9.8 \mathrm{e}-\mathrm{g}$ & $2.4 \mathrm{~cd}$ & $8.1 \mathrm{ab}$ & $33.9 \mathrm{a}$ & $4.9 \mathrm{~cd}$ & $7.3 \mathrm{~b}-\mathrm{d}$ & $17.1 \mathrm{a}-\mathrm{c}$ & $3.7 \mathrm{a}-\mathrm{c}$ & $10.3 \mathrm{c}-\mathrm{e}$ \\
\hline CML 444 & 18 & $5.1 \mathrm{gf}$ & $\ldots$ & $8.2 \mathrm{gf}$ & $10.9 \mathrm{a}$ & $3.4 \mathrm{a}-\mathrm{c}$ & $11.1 \mathrm{e}-\mathrm{g}$ & $0.2 \mathrm{~d}$ & $6.7 \mathrm{~b}-\mathrm{d}$ & $6.1 \mathrm{~d}$ & $2.9 \mathrm{a}-\mathrm{e}$ & $6.1 \mathrm{f}-\mathrm{i}$ \\
\hline R119W & 19 & $47.2 \mathrm{a}$ & $\ldots$ & $30.8 \mathrm{bc}$ & $6.4 \mathrm{~b}$ & $6 a-c$ & $33 \mathrm{ab}$ & $5.0 \mathrm{~cd}$ & $9.9 \mathrm{~b}$ & $10.6 \mathrm{~cd}$ & $3.2 \mathrm{a}-\mathrm{d}$ & $16.9 \mathrm{a}$ \\
\hline CB-222 & 20 & $8.8 \mathrm{e}-\mathrm{g}$ & $\ldots$ & $5.2 \mathrm{gf}$ & $2.0 \mathrm{~cd}$ & $1.8 \mathrm{c}$ & $6.8 \mathrm{~g}$ & $2.7 \mathrm{~cd}$ & $6.4 \mathrm{~b}-\mathrm{d}$ & $8.3 \mathrm{~cd}$ & $2.1 \mathrm{~b}-\mathrm{e}$ & $4.9 \mathrm{hi}$ \\
\hline CB-248 & 21 & $6.5 \mathrm{e}-\mathrm{g}$ & $\ldots$ & $4.8 \mathrm{~g}$ & $3 b-d$ & $5.2 \mathrm{a}-\mathrm{c}$ & $8.2 \mathrm{~g}$ & $10.8 \mathrm{~b}-\mathrm{d}$ & $3.9 \mathrm{c}-\mathrm{e}$ & $5.0 \mathrm{~d}$ & $3.2 \mathrm{a}-\mathrm{d}$ & $5.6 \mathrm{~g}-\mathrm{i}$ \\
\hline CML 390 & 22 & $3.3 \mathrm{~g}$ & $\cdots$ & $8.3 \mathrm{gf}$ & $3.9 \mathrm{~b}-\mathrm{d}$ & $3.6 \mathrm{a}-\mathrm{c}$ & $10.4 \mathrm{gf}$ & $1.7 \mathrm{~cd}$ & $0.0 \mathrm{e}$ & $3.9 \mathrm{~d}$ & $1.3 \mathrm{de}$ & $4.1 \mathrm{i}$ \\
\hline Mean & $\ldots$ & $11.90 \mathrm{~b}$ & $\ldots$ & $16.8 \mathrm{a}$ & $3.3 \mathrm{~b}$ & $4.6 \mathrm{c}$ & $18.6 \mathrm{a}$ & $10.9 \mathrm{~b}$ & $4.4 \mathrm{~b}$ & $10.0 \mathrm{~b}$ & $2.6 \mathrm{~b}$ & 9.23 \\
\hline LSD & $\ldots$ & 7.91 & $\ldots$ & 10.2 & 3.7 & 6.0 & 15.8 & 24.4 & 5.4 & 10.7 & 2.3 & 3.74 \\
\hline
\end{tabular}

y Total fumonisin content is the sum of $\mathrm{FB}_{1}, \mathrm{FB}_{2}$, and $\mathrm{FB}_{3}$; mean total fumonisin concentration for three field plots. Means followed by the same letter in each column are not significantly different according to the Student's $t$ test of least significant differences (LSD, $P \geq 0.05$ ).

${ }^{\mathrm{z}}$ Combined mean. 
temperature, rainfall, and relative humidity $(\mathrm{RH})$ provided conditions for the growth of $F$. verticillioides and the deposition of fumonisins. The highest FER severity and fumonisin contamination in the 2010-11 season at Cedara coincided with significantly cooler temperatures $\left(<25^{\circ} \mathrm{C}\right)$ but the highest percent RH. High FER severity and fungal and fumonisin contamination at Makhatini during 2011-12 occurred under hot $\left(<30^{\circ} \mathrm{C}\right)$ and humid conditions $(<90 \% \mathrm{RH})$. These results suggest that an environment with high $\mathrm{RH}$ and maximum temperature that ensures the growth of $F$. verticillioides provides an ideal setting to evaluate resistance to fumonisin accumulation. Humidity clearly plays an important role in fumonisin contamination. High levels of fumonisins have been reported under hot and dry weather conditions (Shelby et al. 1994), whereas high levels of fumonisins were associated with high RH in Argentina (Hennigen et al. 2000).

Although inbred lines CML 390, US 2540W, and RO 424W were resistant to $F$. verticillioides infection and fumonisin accumulation across localities and seasons, others such as RO 549W, CML 444, and CB 222 were resistant only in specific environments. Thus, it appears that resistant genotypes can have either a broad or specific

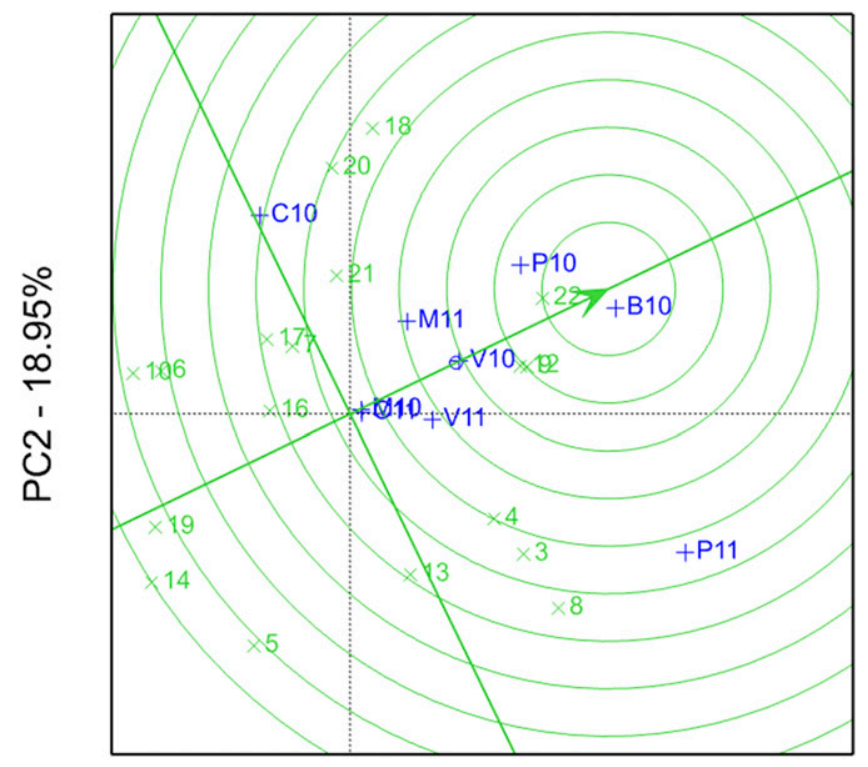

\section{PC1 $-44.34 \%$}

Fig. 6. Genotype main effect and genotype $\times$ environment interaction biplot based on environment-focused scaling for comparison of genotypes for total fumonisin accumulation in 18 maize inbred evaluated during the 2010-11 and 2011-12 seasons. Numbers represent genotypes and localities are represented as Buffelsvallei 2010-11 = B10, Cedara 2010-11 and 2011-12 = C10 and C11, Makhatini 2010-11 and 2011-12 = M10 and M11, Potchefstroom 2010-11 and 2011-12 = P10 and P11, and Vaalharts 2010-11 and 2011-12 = V10 and V11. The circle represents the average principal components $(\mathrm{PC})$ in all environments while distances between genotypes and the ideal genotype are indicated by concentric circles. adaptability to environments. Estimating stability parameters for genotype response to $F$. verticillioides is essential to determine their value across environments. Consequently, hybrids developed from resistant inbred lines could be used to resist $F$. verticillioides and fumonisin accumulation in only specific agroecological zones.

The identification of resistance in breeding lines and the evaluation of commercial hybrids are well documented (Afolabi et al. 2007; Clements et al. 2004; Janse van Rensburg et al. 2015; Small et al. 2012) yet limited information is available on the introgression of resistance into hybrids. No significant improvement in resistance was demonstrated for topcross hybrids developed from inbred lines with significantly improved FER resistance and nearly significant improvement for fumonisin contamination (Eller et al. 2010). Nonetheless, lines that performed well as inbred and hybrid were identified. Therefore, the development of hybrids resistant to FER and fumonisin accumulation may be more complex than anticipated because knowledge on the inheritance of resistance and the general and specific combinability of resistant inbred lines is required. Hung and Holland (2012) demonstrated that inbred performance per se and corresponding general combinability analysis in hybrids were significantly correlated and concluded that an efficient way to improve FER and fumonisin contamination resistance in hybrids is to evaluate and select among inbred lines before using resources to create and evaluate hybrids. Therefore, rigorous screening of inbred lines with agronomically desirable traits for resistance to FER and fumonisin accumulation provides a practical strategy toward the development of resistant hybrids.

Significant correlations between FER severity, $F$. verticillioides colonization, and fumonisin accumulation were found in this study. A significant though moderate relationship between FER and fungal target DNA as well as FER and fumonisin content demonstrates the limitation of solely employing visual assessment to identify sources of resistance. Although the selection of visibly healthy genotypes should, consequently, also exhibit low $F$. verticillioides colonization and fumonisin accumulation, fumonisin-resistant genotypes such as K64R22, R2565y, and I-37 may be discarded based solely on FER severity. Moderate to high heritability and strong genetic correlation between FER and fumonisin resistance in two maize populations determined that visual selection for reduced FER should result in reduced fumonisins yet later generations of inbreds selected for reduced FER warranted evaluation for reduced fumonisin accumulation directly (Robertson-Hoyt et al. 2006).

The relationship between FER severity, $F$. verticillioides colonization, and fumonisin accumulation was reduced by inbred lines VO 617y-2 and RO 549W that had low FER severity and low levels of fungal colonization yet high fumonisin concentrations. Furthermore, inbred lines K64R22, R2565y, and I-37 were susceptible to FER yet had low fungal colonization and fumonisin content. The occurrence of similar discrepancies highlighted the necessity for fumonisin analysis when evaluating maize for resistance (Afolabi et al. 2007; Small et al. 2012). Asymptomatic kernels with high levels of infection and low fumonisin concentrations have been reported (Bush et al. 2004; Desjardins et al. 1998). Factors which affect kernel infection might operate independently from those that affect fumonisin production, thereby affecting the relationship between these two variables (Clements et al.

Table 8. Correlations between Fusarium ear rot severity, Fusarium verticillioides colonization, and total fumonisin content at multiple field locations in South Africa during the 2010-11 and 2011-12 maize-growing seasons ${ }^{\mathrm{z}}$

\begin{tabular}{|c|c|c|c|c|c|c|c|c|c|}
\hline \multirow[b]{2}{*}{ Locality } & \multicolumn{3}{|c|}{ 2010-11 season } & \multicolumn{3}{|c|}{ 2011-12 season } & \multicolumn{3}{|c|}{ Combined across locality } \\
\hline & FER/Fv & FER/FUM & Fv/FUM & FER/Fv & FER/FUM & Fv/FUM & FER/Fv & FER/FUM & Fv/FUM \\
\hline Buffelsvallei & 0.57 & $0.17 * P=0.22$ & 0.59 & N/A & N/A & N/A & 0.57 & $0.17 * P=0.22$ & 0.59 \\
\hline Cedara & 0.32 & $0.22 * P=0.12$ & 0.64 & 0.41 & $0.25^{*} P=0.07$ & 0.67 & 0.47 & 0.40 & 0.70 \\
\hline Makhatini & $0.24 * P=0.08$ & $0.19 * P=0.16$ & 0.57 & $0.12 * P=0.38$ & 0.29 & 0.72 & 0.30 & 0.45 & 0.79 \\
\hline Potchefstroom & 0.57 & 0.56 & 0.92 & $0.26^{*} P=0.06$ & 0.40 & 0.69 & 0.39 & 0.46 & 0.72 \\
\hline Vaalharts & $0.19 * P=0.17$ & $0.06 * P=0.67$ & 0.89 & 0.36 & 0.36 & 0.58 & $0.09 * P=0.34$ & $0.10 * P=0.31$ & 0.84 \\
\hline Combined & 0.43 & 0.36 & 0.59 & 0.24 & 0.25 & 0.73 & 0.36 & 0.31 & 0.64 \\
\hline
\end{tabular}

${ }^{\mathrm{z}} \mathrm{FER}=$ Fusarium ear rot severity $(\%), \mathrm{Fv}=F$. verticillioides target DNA concentration $\left(\mathrm{ng} \mu \mathrm{l}^{-1}\right)$, and $\mathrm{FUM}=$ total fumonisin content $\left(\mathrm{FB}_{1}+\mathrm{FB}_{2}+\mathrm{FB}_{3}\right)\left(\mathrm{mg} \mathrm{kg}^{-1}\right)$;

$*$ indicates not significant $(P>0.05)$; all others significant $(P<0.05)$. 
2003). These results reflect the need for quantifying fumonisins when identifying sources of resistance to $F$. verticillioides and fumonisin accumulation.

The significantly strong correlation between fungal colonization and fumonisin accumulation illustrates the potential of these parameters, in addition to visual disease severity, to more accurately identify sources of resistance. The quantification of $F$. verticillioides target DNA in maize grain will provide a better indication of the potential risk for fumonisin contamination (Janse van Rensburg et al. 2015). The associated cost and expertise required to quantify fungal target DNA or fumonisins may not be practical. This should be weighed against the gains in identifying resistant genotypes to $F$. verticillioides and fumonisin accumulation more accurately, because breeding strategies based on disease severity alone have not demonstrated effective management of fumonisin contamination.

The use of AMMI and GGE biplot analysis to determine the stability of disease resistance through multilocation trials has been described (Pande et al. 2013; Rubiales et al. 2012; Sibiya et al. 2012, 2013). These analyses were employed for the first time to determine and characterize resistance to FER and fumonisin accumulation in maize inbred lines. Functionalities of GGE biplot analysis enabled the comparison of genotypes in all environments and the determination of best-performing genotypes in specific environments. The division of trial localities among different sectors of the polygon view of the GGE biplot further supports the importance of evaluating potential breeding material for resistance to $F$. verticillioides and fumonisin accumulation over several diverse environments.

The response of maize inbred lines to FER severity, F. verticillioides colonization, and fumonisin accumulation was determined across five field localities in South Africa in a 2-year study. Inbred lines resistant to FER and fumonisin accumulation across environments is important, because these lines can be used by seed companies as well-adapted breeding materials. The three inbred lines displaying stable resistance to $F$. verticillioides and fumonisin accumulation could be used in future to develop maize hybrids resistant to FER and fumonisin accumulation. These lines furthermore provide the opportunity to gain knowledge of the genetic processes governing resistance to $F$. verticillioides and fumonisin accumulation in maize.

\section{Acknowledgments}

We thank The South African Maize Trust and the National Research Foundation: Technology and Human Resources for Industry Programme of South Africa for funding of this research; K. Mashingaidze from the ARC-GCI, South Africa, for providing the inbred line seed; A. Schoeman and B. Janse van Rensburg (ARC-GCI) for fungal isolates; $\mathrm{H}$. Vismer from the Medical Research Council, Programme on Mycotoxins and Experimental Carcinogenesis unit, South Africa, for providing the fungal isolate MRC 826; M. van der Rijst and M. Booyse from ARC-Infruitec for statistical analyses; and N. McLaren and B. Janse van Rensburg for critical review of the manuscript.

\section{Literature Cited}

Afolabi, C. G., Ojiambo, P. S., Ekpo, E. J. A., Menkir, A., and Bandyopadhyay, R. 2007. Evaluation of maize inbred lines for resistance to Fusarium ear rot and fumonisin accumulation in grain in tropical Africa. Plant Dis. 91: 279-286.

Bacon, C. W., and Hinton, D. M. 1996. Symptomless endophytic colonization of maize by Fusarium moniliforme. Can. J. Bot. 74:1195-1202.

Bolger, M., Coker, R. D., DiNovi, M., Gaylor, D., Gelderblom, W. C., and Olsen, M. 2001. Fumonisins. Pages 103-279 in: Safety Evaluation of Certain Mycotoxins in Food. Food Addit. Ser. No. 47, FAO Food Nutr. Pap. No. 47. 56th Meet. Joint FAO/WHO Expert Committee Food Addit. (JECFA). World Health Organization (WHO), Geneva, Switzerland.

Boutigny, A.-L., Beukes, I., Small, I., Zühlke, S., Spiteller, M., Van Rensburg, B. J., Flett, B., and Viljoen, A. 2012. Quantitative detection of Fusarium pathogens and their mycotoxins in South Africa. Plant Pathol. 61:522-531.

Bush, B. J., Carson, M. L., Cubeta, M. A., Hagler, W. M., and Payne, G. A. 2004. Infection and fumonisin production by Fusarium verticillioides in developing maize kernels. Phytopathology 94:88-93.

Cao, A., Santiago, R., Ramos, A. J., Souto, X. C., Aquin, O., Malvar, R. A., and Butron, A. 2014. Critical environmental and genotypic factors for Fusarium verticillioides infection, fungal growth and fumonisin contamination in maize grown in northwestern Spain. Int. J. Food Microbiol. 177:63-71.

CFSAN. 2001. Background paper in support of fumonisin levels in corn and corn products intended for human consumption. Docket No. 00D-1277. Online publication. USFDA Center for Food Safety and Applied Nutrition. http:// www.fda.gov/Food/FoodborneIllnessContaminants/NaturalToxins/ucm212899.htm
Clements, M. J., Kleinschmidt, C. E., Pataky, J. K., and White, D. G. 2003. Evaluation of inoculation techniques for Fusarium ear rot and fumonisin contamination of corn. Plant Dis. 87:147-153.

Clements, M. J., Maragos, C. A., Pataky, J. K., and White, D. G. 2004. Sources of resistance to fumonisin accumulation in grain and Fusarium ear and kernel rot of corn. Phytopathology 94:251-260.

Clements, M. J., and White, D. G. 2004. Identifying sources of resistance to aflatoxin and fumonisin contamination in corn grain. J. Toxicol. 23:381-396.

de la Campa, R., Hooker, D. C., Miller, J. D., Schaafsma, A. W., and Hammond, B. G. 2005. Modeling effects of environment, insect damage, and Bt genotypes on fumonisin accumulation in maize in Argentina and the Philippines. Mycopathologia 159:539-552

Desjardins, A. E., Plattner, R. D., Lu, M., and Claflin, L. E. 1998. Distribution of fumonisins in maize ears infected with strains of Fusarium moniliforme that differ in fumonisin production. Plant Dis. 82:953-958.

Duncan, K. E., and Howard, R. J. 2010. Biology of maize kernel infection by Fusarium verticillioides. Mol. Plant-Microbe Interact. 23:6-16.

Eller, M. S., Holland, J. B., and Payne, G. A. 2008. Breeding for improved resistance to fumonisin contamination in maize. Toxin Rev. 27:371-389.

Eller, M. S., Payne, G. A., and Holland, J. B. 2010. Selection for reduced Fusarium ear rot and fumonisin content in advanced backcross maize lines and their topcross hybrids. Crop Sci. 50:2249-2260.

Foley, D. C. 1962. Systemic infection of corn by Fusarium moniliforme. Phytopathology 52:870-872.

Franceschi, S., Bidoli, E., Baron, A. E., and La Veccbia, C. 1990. Maize and risk of cancers of the oral cavity, pharynx and esophagus in Northern Italy. J. Natl. Cancer Inst. 82:1407-1411.

Gabriel, K. R. 1971. The biplot graphic display of matrices with application to principal component analysis. Biometrics 58:453-467.

Gelderblom, W. C. A., Cawood, M. E., Snyman, S. D., and Marasas, W. F. O. 1994. Fumonisin $B_{1}$ dosimetry in relation to cancer initiation in rat-liver. Carcinogenesis 15:209-214.

Gelderblom, W. C. A., Jaskiewicz, K., Marasas, W. F. O., Thiel, P. G., Horak, R. M., Vleggaar, R., and Kriek, N. P. J. 1988. Fumonisins-novel mycotoxins with cancer-promoting activity produced by Fusarium moniliforme. Appl. Environ. Microbiol. 54:1806-1811.

Headrick, J. M., and Pataky, J. K. 1991. Maternal influence on the resistance of sweet corn lines to kernel infection by Fusarium moniliforme. Phytopathology 81:268-274.

Hennigen, M. R., Valente Soares, L. M., Sanchez, S., Di Benedetto, N. M., Longhi, A., Eyherabide, G., Torroba, J., and Zanelli, M. 2000. Fumonisin in corn hybrids grown in Argentina for two consecutive seasons. Pages 331-339 in: Proc. Xth Int. IUPAC Symp. Mycotoxins Phytotoxins. W. J. De Koe, R. A. Samson, H. P. van Egmond, J. Gilbert, and M. Sabino, eds.

Hung, H.-Y., and Holland, J. B. 2012. Diallel analysis of resistance to Fusarium ear rot and fumonisin contamination in maize. Crop Sci. 52:2173-2181.

Janse van Rensburg, B., McLaren, N. W., Flett, B. C., and Schoeman, A. 2015. Fumonisin producing Fusarium spp. and fumonisin contamination in commercial South African maize. Eur. J. Plant Pathol. 141:491-504.

Kellerman, T. S., Marasas, W. F., Thiel, P. G., Gelderblom, W. C., Cawood, M. and Coetzer, J. A. 1990. Leukoencephalomalacia in two horses induced by oral dosing of fumonisin $B_{1}$. Onderstepoort J. Vet. Res. 57:269-275.

Koehler, B. 1942. Natural mode of entrance of fungi into corn ears and some symptoms that indicate infection. J. Agric. Res. 64:421-442.

Kommedahl, T., and Windels, C. E. 1981. Root-, stalk-, and ear-infecting Fusarium species on corn in the USA. Pages 94-103 in: Fusarium: Diseases, Biology, and Taxonomy. P. E. Nelson, T. A. Toussoun, and R. J. Cook, eds. Penn State University Press, University Park.

Marasas, W. F. O., Kellerman, T. S., Gelderblom, W. C. A., Coetzer, J. A. W., Thiel, P. G., and Van der Lugt, J. J. 1988. Leukoencephalomalacia in a horse induced by fumonisin $\mathrm{B}_{1}$ isolated from Fusarium moniliforme. Onderstepoort J. Vet. Res. 55:197-203

Marasas, W. F. O., Wehner, F. C., van Rensburg, S. J., and van Schalkwyk, D. J. 1981. Mycoflora of corn produced in human esophageal cancer areas in Transkei, southern Africa. Phytopathology 71:792-796.

Missmer, S. A., Suarez, L., Felkner, M., Wang, E., Jr., Merrill, A. H., Rothman, K. J., and Hendricks, K. A. 2006. Exposure to fumonisins and the occurrence of neural tube defects along the Texas-Mexico border. Environ. Health Perspect. 114:237-241.

Mitrovic, B., Stanisavljevi, D., Treski, S., Stojakovic, M., Ivanovic, M., Bekavac, G., and Rajkovic, M. 2012. Evaluation of experimental maize hybrids tested in multilocation trials using AMMI and GGE biplot analysis. Turk. J. Field Crops 17:35-40.

Munkvold, G. P., and Carlton, W. M. 1997. Influence of inoculation method on systemic Fusarium moniliforme infection of maize plants grown from infected seeds. Plant Dis. 81:211-216.

Munkvold, G. P., McGee, D. C., and Carlton, W. M. 1997. Importance of different pathways for maize kernel infection by Fusarium moniliforme. Phytopathology 87:209-217.

Ncube, E., Flett, B. C., Waalwijk, C., and Viljoen, A. 2011. Fusarium spp. and levels of fumonisins in maize produced by subsistence farmers in South Africa. S. Afr. J. Sci. 107:1-7.

Oren, L., Ezrati, S., Cohen, D., and Sharon, A. 2003. Early events in the Fusarium verticillioides-maize interaction characterized by using a green fluorescent protein-expressing transgenic isolate. Appl. Environ. Microbiol. 69:1695-1701. 
Osuchowski, M. F., Edwards, G. L., and Sharma, R. P. 2005. Fumonisin $\mathrm{B}_{1}$-induced neurodegeneration in mice after intracerebroventricular infusion is concurrent with disruption of sphingolipid metabolism and activation of proinflammatory signaling. Neurotoxicology 26:211-221.

Pande, S., Sharma, M., Gaur, P. M., Basandrai, A. K., Kaur, L., Hooda, K. S., Basandrai, D., Kiran Babu, T., Jain, S. K., and Rathore, A. 2013. Biplot analysis of genotype $\times$ environment interactions and identification of stable sources of resistance to Ascochyta blight in chickpea (Cicer arietinum L.). Australas. Plant Pathol. 42:561-571.

Payne, R., Murray, D. A., Harding, S. A., Baird, D. B., and Soutar, D. M. 2013. GenStat for Windows, 16th ed. Introduction to GenStat for Windows. VSN International, Hemel, Hempstead, UK.

Pérez-Brito, D., Jeffers, D., González-de-León, D., Khairallah, M., Cortés-Cruz, M., Velázquez-Cardelas, G., Azpíroz-Rivero, S., and Srinivasan, G. 2001. QTL mapping of Fusarium moniliforme ear rot resistance in highland maize, México. Agrociencia 35:181-196

Purchase, J. L., Hatting, H., and Van Deventer, C. S. 2000. Genotype $\times$ environment interaction of winter wheat ( $T$. aestivum) in South Africa: Stability analysis of yield performance. S. Afr. J. Plant Soil 17:101-107.

Rheeder, J. P., Marasas, W. F. O., Thiel, P. G., Sydenham, E. W., Shephard, G. S., and Van Schalkwyk, D. J. 1992. Fusarium moniliforme and fumonisins in corn in relation to human esophageal cancer in Transkei. Phytopathology 82:353-357.

Rheeder, J. P., Marasas, W. F. O., Van Wyk, P. S., Du Toit, W., Pretorius, A. J., and Van Schalkwyk, D. J. 1990. Incidence of Fusarium and Diplodia species and other fungi in naturally infected grain of South African maize cultivars. Phytophylactica 22:97-102

Riaz, M., Naveed, M., Farooq, J., Farooq, A., Mahmood, A., Rafiq, C. M., Nadeem, M., and Sadiq, A. 2013. AMMI analysis for stability, adaptability and GE interaction studies in cotton (Gossypium hirsutum L.). J. Anim. Plant Sci. 23:865-871.

Robertson, L. A., Kleinschmidt, C. E., White, D. G., Payne, G. A., Maragos, C. M., and Holland, J. B. 2006. Heritabilities and correlations of Fusarium ear rot resistance and fumonisin contamination resistance in two maize populations. Crop Sci. 46:353-361.

Robertson-Hoyt, L. A., Betran, J., Payne, G. A., White, D. G., Isakeit, T., Maragos, C. M., Molnar, T. L., and Holland, J. B. 2007. Relationships among resistances to Fusarium and Aspergillus ear rots and contamination by fumonisin and aflatoxin in maize. Phytopathology 97:311-317.

Robertson-Hoyt, L. A., Jines, M. P., Balint-Kurti, P. J., Kleinschmidt, C. E., White, D. G., Payne, G. A., Maragos, C. M., Molnár, T. L., and Holland, J. B. 2006. QTL mapping for Fusarium ear rot and fumonisin contamination resistance in two maize populations. Crop Sci. 46:1734-1743.
Rubiales, D., Avila, C. M., Sillero, J. C., Hybl, M., Narits, L., Sass, O., and Flores, F. 2012. Identification and multi-environment validation of resistance to Ascochyta fabae in faba bean (Vicia faba). Field Crops Res. 126:165-170.

Shelby, R. A., White, D. G., and Bauske, E. M. 1994. Differential fumonisin production in maize hybrids. Plant Dis. 78:582-584.

Shephard, G. S. 2008. Impact of mycotoxins on human health in developing countries. Food Addit. Contam. 25:146-151.

Shephard, G. S., Marasas, W. F. O., Burger, H. M., Somdyala, N. I. M., Rheeder, J. P., van der Westhuizen, L., Gatyeni, P., and van Schalkwyk, D. J. 2007. Exposure assessment for fumonisins in the former Transkei region of South Africa. Food Addit. Contam. 24:621-629.

Shephard, G. S., Thiel, P. G., Stockenstrom, S., and Sydenham, E. W. 1996 Worldwide survey of fumonisin contamination of corn and corn-based products. J. AOAC Int. 79:671-687.

Sibiya, J., Tongoona, P., and Derera, J. 2013. Combining ability and GGE biplot analyses for resistance to northern leaf blight in tropical and subtropical elite maize inbred lines. Euphytica 191:245-257.

Sibiya, J., Tongoona, P., Derera, J., and Rij, N. V. 2012. Genetic analysis and genotype by environment $(\mathrm{G} \times \mathrm{E})$ for grey leaf spot disease resistance in elite African maize (Zea mays L.) germplasm. Euphytica 185:349-362.

Small, I. M., Flett, B. C., Marasas, W. F. O., McLeod, A., Stander, M. A., and Viljoen, A. 2012. Resistance in maize inbred lines to Fusarium verticillioides and fumonisin accumulation in South Africa. Plant Dis. 96:881-888.

Smeltzer, D. G. 1959. Relationship between Fusarium ear rot and corn earworm infestation. Agron. J. 51:53-54.

Williams, J. H., Grubb, J. A., Davis, J. W., Wang, J., Jolly, P. E., Ankrah, N., Ellis, W. O., Afriyie-Gyawu, E., Johnson, N. M., Robinson, A. G., and Phillips, T. D. 2010. HIV and hepatocellular and esophageal carcinomas related to consumption of mycotoxin-prone foods in sub-Saharan Africa. Am. J. Clin. Nutr. 92:154-160.

Wu, L., Wang, X.-M., Xu, R.-Q., and Li, H.-J. 2011. Root infection and systematic colonisation of DsRed-labeled Fusarium verticillioides in maize. Acta Agron. Sin. 37:793-802.

Yan, W. 2001. GGE biplot - a Windows application for graphical analysis of multienvironment trial data and other types of two way data. Agron. J. 93:1111-1118

Yan, W., Hunt, L. A., Sheng, Q., and Szlavnics, Z. 2000. Cultivar evaluation and megaenvironment investigation based on the GGE Biplot. Crop Sci. 40:597-605.

Yan, W., and Kang, M. 2003. GGE Biplot Analysis: A Graphical Tool for Breeders, Geneticists and Agronomists. CRC Press, Boca Raton, FL.

Zila, C. T., Samayoa, L. F., Santiago, R., Butron, A., and Holland, J. B. 2013. A genome-wide association study reveals genes associated with Fusarium ear rot resistance in a maize core diversity panel. G3: Genes Genomes Genet. 3:2095-2104. 